NBER WORKING PAPER SERIES

\title{
THE ROLE OF BOARDS OF DIRECTORS IN CORPORATE GOVERNANCE: A CONCEPTUAL FRAMEWORK AND SURVEY
}

\author{
Renée Adams \\ Benjamin E. Hermalin \\ Michael S. Weisbach \\ Working Paper 14486 \\ http://www.nber.org/papers/w14486 \\ NATIONAL BUREAU OF ECONOMIC RESEARCH \\ 1050 Massachusetts Avenue \\ Cambridge, MA 02138 \\ November 2008
}

The authors wish to thank Ji-Woong Chung, Rudiger Fahlenbrach, and Eliezer Fich for helpful comments on earlier drafts. The views expressed herein are those of the author(s) and do not necessarily reflect the views of the National Bureau of Economic Research.

NBER working papers are circulated for discussion and comment purposes. They have not been peerreviewed or been subject to the review by the NBER Board of Directors that accompanies official NBER publications.

(C) 2008 by Renée Adams, Benjamin E. Hermalin, and Michael S. Weisbach. All rights reserved. Short sections of text, not to exceed two paragraphs, may be quoted without explicit permission provided that full credit, including $(\mathcal{O}$ notice, is given to the source. 
The Role of Boards of Directors in Corporate Governance: A Conceptual Framework and Survey

Renée Adams, Benjamin E. Hermalin, and Michael S. Weisbach

NBER Working Paper No. 14486

November 2008

JEL No. G3,L22

\begin{abstract}
This paper is a survey of the literature on boards of directors, with an emphasis on research done subsequent to the Hermalin and Weisbach (2003) survey. The two questions most asked about boards are what determines their makeup and what determines their actions? These questions are fundamentally intertwined, which complicates the study of boards due to the joint endogeneity of makeup and actions. A focus of this survey is on how the literature, theoretical as well as empirically, deals - or on occasions fails to deal - with this complication. We suggest that many studies of boards can best be interpreted as joint statements about both the director-selection process and the eect of board composition on board actions and rm performance.
\end{abstract}

Renée Adams

UQ Business School

University of Queensland

Brisbane, Qld 4072

Australia

r.adams@business.uq.edu.au

Benjamin E. Hermalin

Walter Haas School of Business

545 Student Services Building, \#1900

University of California

Berkeley, CA 94720-0001

hermalin@haas.berkeley.edu
Michael S. Weisbach

Department of Finance

Fisher College of Business

2100 Neil Ave.

Columbus, $\mathrm{OH} 43210$

and NBER

weisbach_2@fisher.osu.edu 


\section{Introduction}

People often question whether corporate boards matter because their day-today impact is difficult to observe. But, when things go wrong, they can become the center of attention. Certainly this was true of the Enron, Worldcom, and Parmalat scandals. The directors of Enron and Worldcom, in particular, were held liable for the fraud that occurred: Enron directors had to pay $\$ 168$ million to investor plaintiffs, of which $\$ 13$ million was out of pocket (not covered by insurance); and Worldcom directors had to pay $\$ 36$ million, of which $\$ 18$ million was out of pocket. ${ }^{1}$ As a consequence of these scandals and ongoing concerns about corporate governance, boards have been at the center of the policy debate concerning governance reform and the focus of considerable academic research. Because of this renewed interest in boards, a review of what we have and have not learned from research on corporate boards is timely.

Much of the research on boards ultimately touches on the question "what is the role of the board?" Possible answers range from boards' being simply legal necessities, something akin to the wearing of wigs in English courts, to their playing an active part in the overall management and control of the corporation. No doubt the truth lies somewhere between these extremes; indeed, there are probably multiple truths when this question is asked of different firms, in different countries, or in different periods.

Given that all corporations have boards, the question of whether boards play a role cannot be answered econometrically as there is no variation in the explanatory variable. Instead, studies look at differences across boards and ask whether these differences explain differences in the way firms function and how they perform. The board differences that one would most like to capture are differences in behavior. Unfortunately, outside of detailed field work, it is difficult to observe differences in behavior and harder still to quantify them in a way useful for statistical study. Consequently, empirical work in this area has focused on structural differences across boards that are presumed to correlate with differences in behavior. For instance, a common presumption is that outside (non-management) directors will behave differently than inside (management) directors. One can then look at the conduct of boards (e.g., decision to dismiss the CEO when financial performance is poor) with different ratios of outside to inside directors to see whether conduct varies in a statistically significant manner across different ratios. When conduct is not directly observable (e.g., advice to the CEO about strategy), one can look at a firm's financial performance to see whether board structure matters (e.g., the way accounting profits vary with the ratio of outside to inside directors).

One problem confronting such an empirical approach is that there is no reason to suppose board structure is exogenous; indeed, there are both theoretical arguments and empirical evidence to suggest board structure is endogenous (see, e.g., Hermalin and Weisbach, 1988, 1998, and 2003). This creates problems for the estimation of structure-conduct and structure-performance regressions.

\footnotetext{
${ }^{1}$ Klausner et al. (2005).
} 
In fact, one of our main points in this survey is the importance of endogeneity. Governance structures arise endogenously because economic actors choose them in response to the governance issues they face. ${ }^{2}$

Beyond the implications endogeneity holds for econometric analysis, it also has implications for how to view actual governance practice. In particular, when we observe what appears to be a poor governance structure, we need to ask why that structure was chosen. Although it is possible that the governance structure was chosen by mistake, one needs to give at least some weight to the possibility that it represents the right, albeit poor, solution to the constrained optimization problem the organization faces. After all, competition in factor, capital, and product markets should lead, in Darwinian fashion, to the survival of the fittest. While admittedly "fittest" does not mean "optimal," anything that was sub-optimal for known reasons would be unfit insofar as there would be pressure to address these reasons for sub-optimality. In other words, existing sub-optimality is unlikely to lend itself to quick or obvious fixes.

This insight about endogeneity is, however, easy to forget in the face of data. Figure 1 shows a plot of two data points. ${ }^{3}$ On the horizontal axis is an attribute of governance (e.g., board size). On the vertical axis is a measure of financial performance. One firm has more of the attribute, but weaker performance; while the other firm has less of the attribute, but better performance. A regression line through the points underscores the apparent negative relation between attribute and performance. Without further analysis, one might be tempted to conclude that a firm would do better if it shrank the size of its board. The problem with such a conclusion is that it fails to consider why a large board might have been chosen.

Figure 2 replicates Figure 1, but it also shows the optimization problems faced by the two firms in question. Observe that, for a given firm, there is a non-monotonic relation between the attribute and financial performance. In particular, the relation is concave and admits an interior maximum. Moreover, each of the two firms is at its maximum. Consequently, whereas Firm 2 would prefer ceteris paribus to be on Firm 1's curve, it isn't and, thus, would do worse than it is doing if it were to shrink its board in line with the naïve conclusion drawn from the regression in Figure 1.

Figures 1 and 2 illustrate another issue confronting the study of governance, namely heterogeneity in the solutions firms choose for their governance problems. ${ }^{4}$ As illustrated, Firms 1 and 2 face different governance problems and, not

\footnotetext{
${ }^{2}$ Demsetz and Lehn (1985) were among the first to make the general point that governance structures are endogenous. Others who have raised it include Himmelberg et al. (1999), Palia (2001), and Coles et al. (2007). The point has also been discussed in various surveys of the literature; consider, e.g., Bhagat and Jefferis (2002) and Becht et al. (2003), among others.

${ }^{3}$ Figure 1 is presented for illustrative purposes and should not be read as a critique of any existing research. In particular, no analysis is as naïve as Figure 1.

${ }^{4}$ To be sure, a real empirical study would attempt, in part, to control for such heterogenity by putting in other controls, including if the data permitted, firm fixed effects. It should be noted, however, that (i) there can still be a problem with the specification if the attribute enters
} 


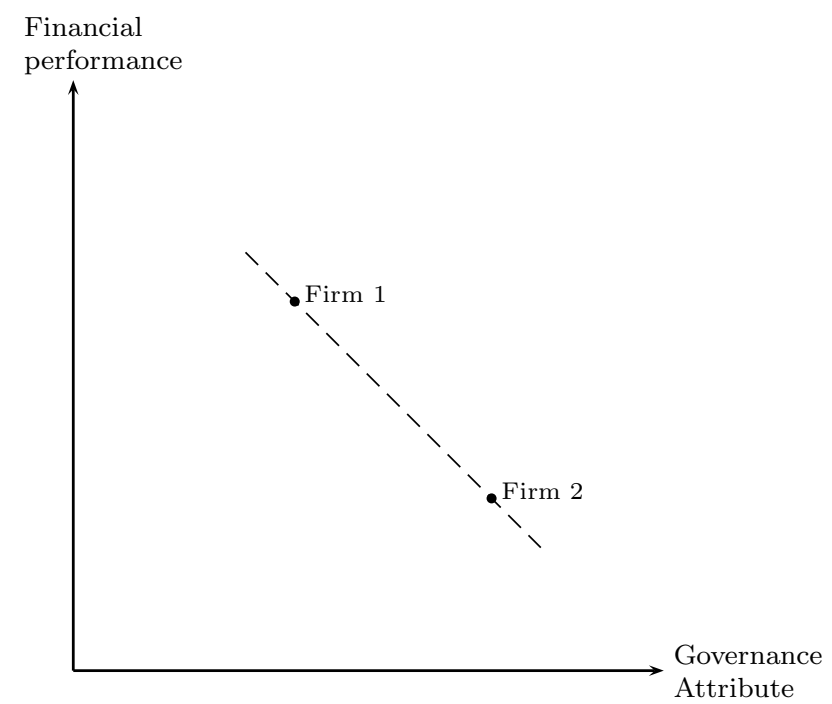

Figure 1: Relation between a specific firm attribute and firm financial performance.

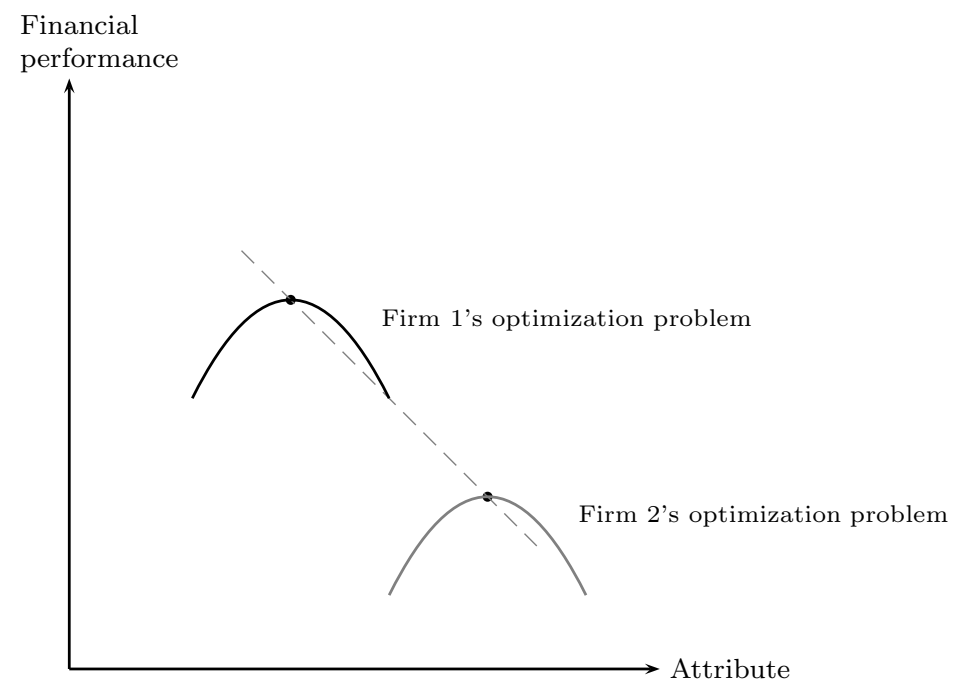

Figure 2: The real decisions faced by the firms. 
surprisingly, are driven to different solutions. Almost every model of governance shows that the equilibrium outcome is sensitive to its exogenous parameters; consequently, heterogeneity in those parameters will lead to heterogeneity in solutions. Moreover, once one takes into account various sources of non-convexity, such as those arising in optimal incentive schemes, one may find that strategic considerations lead otherwise identical firms to adopt different governance solutions (see, e.g., Hermalin, 1994).

Some help with the heterogeneity issue could be forthcoming from more theoretical analyses. Although a common - and not necessarily inaccurateperception of the literature on corporate governance, particularly related to boards of directors, is that it is largely empirical, such a view overlooks a large body of general theory that is readily applied to the specific topic of boards. For instance, monitoring by the board would seem to fit into the general literature on hierarchies and supervision (e.g., Williamson, 1975, Calvo and Wellisz, 1979, Kofman and Lawarrée, 1993, and Tirole, 1986, 1992). As a second example, issues of board collaboration would seem to fit into the general literature on free-riding and the teams problem (see, e.g., Holmstrom, 1982).

The teams-problem example serves to illustrate a problem that can arise in applying "off-the-shelf" theory to boards. It is well known that, as a member's share of a team's output falls, he or she supplies less effort. For boards, however, the question is not a single director's effort, but what happens to total effort (e.g., are larger boards less capable monitors because of the teams problem)? Yet, here, theory cannot provide a definitive answer - whether total equilibrium effort increases or not with board size depends critically on assumptions about functional forms. ${ }^{5}$ While "anything goes" conclusions can be acceptable in an abstract theoretical model, they are often less than satisfactory in applied modeling. The lack of clear definitive predictions in much of the related general theory is, therefore, a hindrance to modeling governance issues. Conversely, if a specific model makes a definitive prediction, then one can often be left wondering if it is an artifact of particular assumptions rather than a reflection of a robust economic truth.

A second, related point is that, in a simplified, and thus tractable, model, theory can be too strong; that is, by application of sophisticated contracts or mechanisms the parties (e.g., directors and CEO) can achieve a more optimal outcome than reality indicates is possible. To an extent, that problem can be finessed; for instance, if one restricts attention to incomplete contracts. But as

into the specification only linearly (as opposed to nonlinearly as suggested by the parabolas in Figure 2); and (ii) if different firms face different shaped tradeoffs (e.g., if the parabolas aren't the same shape for all firms), then the coefficients on the attribute, its square, etc., will vary across firms, suggesting a random-coefficients approach is warranted. See Hermalin and Wallace (2001) and Bhagat and Jefferis (2002) for a discussion of some of these methodological issues.

${ }^{5}$ For instance, if a team's total benefit is $\sum_{n=1}^{N} e_{n}$, where $e_{n}$ is the effort of agent $n$, each agent gets $1 / N$ of the benefit, and each agent $n$ 's utility is $\left(\sum_{m=1}^{N} e_{m}\right) / N-\left(e_{n}^{\gamma+1}\right) /(\gamma+1)$, then total equilibrium effort is $N\left(\frac{1}{N}\right)^{1 / \gamma}$, which is increasing in $N$ if $\gamma>1$, decreasing in $N$ if $\gamma \in(0,1)$, and constant if $\gamma=1$. 
others have noted, the assumption of incomplete contracts can fail to be robust to minor perturbations of the information structure (Hermalin and Katz, 1991) or the introduction of a broader class of mechanisms (Maskin and Tirole, 1999).

A further issue is that corporations are complex, yet, to have any traction, a model must abstract away from many features of real-life corporations. This makes it difficult to understand the complex and multifaceted solutions firms use to solve their governance problems. For instance, the optimal governance structure might involve a certain type of board, operating in a certain fashion, having implemented a particular incentive package, and responding in certain ways to feedback from the relevant product and capital markets. To include all those features in a model is infeasible, but can we expect the assumption of ceteris paribus with respect to the non-modeled aspects of the situation to be reasonable? The constrained answer arrived at by holding all else constant need not represent the unconstrained answer accurately.

Yet another point, related both to the previous point and to our emphasis on issues of endogeneity, is that, motivated by both a desire to simplify and to conform to institutional details, the modeler is often tempted to take certain aspects of the governance structure as given. The problem with this is that the governance structure is largely endogenous; it is, in its entirety, the solution reached by economic actors to their governance problems. Of course, certain features, such as the necessity of having a board of directors, can largely be seen as exogenous (although it should be remembered that the decision to make a company a corporation rather than, say, a partnership is itself endogenous). Furthermore, the timing of events, particularly in the short run, can make it reasonable to treat some aspects of the governance structure as exogenous for the purposes of investigating certain questions theoretically.

In this survey, we focus primarily on work that illustrates the sorts of challenges discussed above, papers that help clarify the nature of board behavior, or that use novel approaches. We also attempt to put the work under the same conceptual microscope, namely how should the results be interpreted in light of governance structures being the second-best solution to the governance problems faced by the firm. Our focus is also on more recent papers, even if they are not yet published, because prior surveys by John and Senbet (1998) and Hermalin and Weisbach (2003) cover many established papers in this field. Although we aim to be comprehensive, it would be impossible to discuss every paper in light of the recent explosion in the literature on boards. ${ }^{6}$ Of necessity, we omit many interesting papers in this area and we apologize to their authors in advance. For a more detailed discussion of the event-study evidence surrounding board appointments, we refer the reader to Yermack (2006). Fields and Keys (2003) review the monitoring role of the board, as well as the emerging literature on board diversity (see, also, Carter et al., 2003, Farrell and Hersch, 2005, and Adams and Ferreira, 2008b, on board diversity). For the sake of brevity, we do not discuss the literature on boards of financial institutions. Because this

\footnotetext{
${ }^{6}$ After searching the literature, we estimate that more than 200 working papers on boards have been written since 2003, when Hermalin and Weisbach published their board survey.
} 
is a survey of corporate boards, we also do not discuss the literature on boards of organizations such as non-profits and central banks. Partly because of the difficulty in obtaining data, this literature is less developed than the literature on corporate boards (Bowen, 1994, discusses some of the similarities and differences between corporate and non-corporate boards). ${ }^{7}$ Similar data limitations restrict us to a discussion of boards of publicly-traded corporations.

Boards have also been a subject of interest in many disciplines beyond economics and finance, including accounting, law, management, psychology, and sociology. ${ }^{8}$ Each of these literatures provide fascinating insights into the nature of boards. Although this survey focuses on the economics and finance literatures, it is worth noting that the study of boards is interdisciplinary.

The next section considers the question of what directors do. The section following, Section 3, considers issues related to board structure. Section 4 discusses how boards fulfill their roles. Section 5 examines the literature on what motivates directors. We end with some concluding remarks.

\section{What Do Directors Do?}

To understand corporate boards, one should begin with the question of what do directors do? ${ }^{9}$

\subsection{Descriptive Studies}

One way to determine what directors do is to observe directors; that is, do field work. There is a large descriptive literature on boards (e.g., Mace, 1971, Whisler, 1984, Lorsch and MacIver, 1989, Demb and Neubauer, 1992, and Bowen, 1994).

The principal conclusions of Mace were that "directors serve as a source of advice and counsel, serve as some sort of discipline, and act in crisis situations" if a change in CEO becomes necessary (p. 178). The nature of their "advice and counsel" is unclear. Mace suggests that a board serves largely as a sounding board for the CEO and top management, occasionally providing expertise when a firm faces an issue about which one or more board members are expert. Yet Demb and Neubauer's survey results find that approximately two-thirds of directors agreed that "setting the strategic direction of the com-

\footnotetext{
${ }^{7}$ Also see Hermalin (2004) for a discussion of how research on corporate boards may inform the study of university and college boards. Freedman (2004) discusses the relation between universities and colleges' boards and their presidents.

${ }^{8}$ Some examples of this broader literature include Bebchuk and Fried (2004), Demb and Neubauer (1992), Grandori, ed (2004), Hambrick et al. (1996), Lorsch and MacIver (1989), Mace (1971), Pfeffer (1972), Roe (1994), Westphal and Zajac (1995), Westphal (1999), and Zajac and Westphal (1996).

${ }^{9}$ This question is distinct from the question of what should directors do? This second question is answered, in part, by the legal obligations imposed by corporate law (both statute and precedent), having to do with fiduciary obligations (see, e.g., Clark, 1986, especially chapters 3 and 4 ).
} 
pany" was one of the jobs they did (p. 43, emphasis added). ${ }^{10}$ Eighty percent of the directors also agreed that they were "involved in setting strategy for the company" (p. 43). Seventy-five percent of respondents to another of Demb and Neubauer's questionnaires report that they "set strategy, corporate policies, overall direction, mission, vision" (p. 44). Indeed far more respondents agreed with that description of their job than agreed with the statements that their job entailed "oversee[ing], monitor[ing] top management, CEO" (45\%); "succession, hiring/firing CEO and top management" (26\%); or serving as a "watchdog for shareholders, dividends" (23\%).

The disciplinary role of boards is also unclear from descriptive studies. Perhaps reflecting the period he studied, Mace suggests that discipline stems largely from the CEO and other top management knowing "that periodically they must appear before a board made up largely of their peers" (p. 180). Lorsch and MacIver take an even dimmer view, suggesting that boards are so passive that they offer little by way of discipline (see, especially, p. 96). Demb and Neubauer's statistics seem broadly consistent with this view, as less than half of their respondents agree that their job is to "oversee, monitor top management, CEO" and less than a quarter agree that their job is to serve as a "watchdog for shareholders, dividends" (p. 44).

On the other hand, it has been suggested that the board passivity described by Mace and Lorsch and MacIver is a phenomenon of the past. For instance, MacAvoy and Millstein (1999) suggest that boards have recently become less passive; that is, they have evolved from being "managerial rubber-stamps to active and independent monitors." MacAvoy and Millstein provide statistical evidence in support of that conclusion, finding that CalPERS' grading of a firm's board procedures is positively correlated with accounting-based measures of performance. Another piece of evidence consistent with the view that boards have become tougher is that CEO dismissal probabilities have been trending upward (see Huson et al., 2001, for evidence over the period 1971 to 1994 and see Kaplan and Minton, 2006, for more recent evidence).

\subsection{The Hiring, Firing, and Assessment of Management}

One role that is typically ascribed to directors is control of the process by which top executives are hired, promoted, assessed, and, if necessary, dismissed (see, e.g., Vancil, 1987, for a descriptive analysis and Naveen, 2006, for statistical evidence).

Assessment can be seen as having two components, one is monitoring of what top management does and the other is determining the intrinsic ability of top management. The monitoring of managerial actions can, in part, be seen as part of a board's obligation to be vigilant against managerial malfeasance. Yet, being realistic, it is difficult to see a board actually being in a position to

\footnotetext{
${ }^{10}$ It is important to note that the Demb and Neubauer surveys and questionnaires sample very few American directors (4.2\%). The top four nationalities surveyed by them are British (29.6\%), German (11.3\%), French (11.3\%), and Canadian (9.9\%). Overall $43.7 \%$ of their respondents come from common-law countries.
} 
detect managerial malfeasance directly; at best, a board would seem dependent on the actions of outside auditors, regulators, and, in some instances, the news media. Indirectly, a board might guard against managerial malfeasance through its choice of auditor, its oversight over reporting requirements, and its control over accounting practices.

The principal focus of the literature on assessment, at least at a theoretical level, has been on the question of how the board determines managerial ability and what it does with that information. ${ }^{11}$ One strategy for studying the question of ability assessment has been the adaptation of Holmstrom (1999) to boards. Within that broad approach, authors have focussed on how the assessment of ability relates to the power of the CEO (e.g., Hermalin and Weisbach, $1998)$; to the selection of projects and strategy (e.g., Dominguez-Martinez et al., in press); to the process of selecting the CEO (e.g., Hermalin, 2005); among other issues.

\subsubsection{Assessment, Bargaining Power, and CEO Control}

The first article to apply Holmstrom's framework to boards was Hermalin and Weisbach (1998). In their model, there is an initial period of firm performance under an incumbent CEO. Based on this performance, the board updates its beliefs about the CEO's ability. In light of these updated beliefs, the board may choose to dismiss the CEO and hire a replacement from the pool of replacement CEOs or it may bargain with the incumbent CEO with regard to changes in board composition and his future salary. The board, then, chooses whether to obtain an additional, costly signal about CEO ability (either that of the original incumbent if retained or the replacement if hired). ${ }^{12}$ Based on this signal, if obtained, the board again makes a decision about keeping or replacing the CEO. If replaced, a (another) CEO is drawn from the pool of replacement CEOs. Finally, second- (and final-) period profits are realized, with the expected value of the profits being a positive function of the then-in-charge CEO's ability.

The board's inclination to obtain an additional signal is a function of its independence from the CEO. ${ }^{13}$ The board's independence at that stage will depend

\footnotetext{
${ }^{11}$ Typically, the CEO is a member of the board. In stating the CEO is at odds with "the board," we are, like the literature, using the board as shorthand for the board minus the CEO.

${ }^{12}$ An alternative, but essentially equivalent, modeling strategy for this stage would be to assume the board always receives the additional signal, but the board has discretion over the informativeness of the signal, with more informative signals being costlier to the board than less informative signals. See the discussion in Hermalin (2005) on this matter.

${ }^{13}$ Independence is a complex concept. With respect to monitoring the CEO, one imagines that directors who have close ties to the CEO (e.g., professionally, socially, or because the CEO has power over them) would find monitoring him more costly than directors with fewer ties. In terms of measurable aspects of board structure, outside directors are typically taken to be more independent than inside directors, given the latter are either the CEO or his subordinates. Some empirical work tries to further analyze the reported ties between outside directors and the CEO, dividing outside directors according to their level of independence (e.g., Baysinger and Butler, 1985; Hermalin and Weisbach, 1988, 1991). This division of outsiders is almost always dichotomous with the two categories being independent outsiders and "gray" directors, with the latter referring to directors with reported social or professional ties to the CEO. Some authors use the term "affiliated" instead of "gray."
} 
on the outcome of the bargaining game between the board and the incumbent CEO if he is retained. ${ }^{14}$ Because the acquisition of the additional signal can only increase the risk of being dismissed and the CEO enjoys a non-contractible control benefit, the CEO prefers a less independent board; that is, a board less likely to acquire this additional signal. The board, however, prefers to maintain its independence. When the CEO has bargaining power - specifically when he has demonstrated that he's a "rare commodity" by performing well- the board's independence declines. Intuitively, a CEO who has shown himself to be above average bargains on two dimensions: he can bargain for more compensation and, because he prefers to remain CEO over being fired, the degree of the board's independence. At any moment in time, a board views itself as optimally independent (i.e., the directors view any change in their composition that may lead to more or less diligence in monitoring as moving it away from the incumbent board's optimum). Hence, a change in independence represents a second-order loss for the board, whereas as an increase in the CEO's salary is a first-order loss. The board, therefore, is more willing to budge on the issue of independence (willingness to monitor) than salary and, hence, there is more movement on independence. So a CEO who performs well ends up facing a less independent board. The flip side is that a CEO who performs poorly is vulnerable to replacement.

Baker and Gompers (2003), Boone et al. (2007), and Ryan and Wiggins (2004) each find evidence consistent with the idea that successful CEOs are able to bargain for less independent boards. Boone et al. find that variables that are reasonably associated with bargaining power either for the board or the CEO are significant and have the right sign. In particular, measures of CEO bargaining power, tenure, and the CEO's shareholdings, are negatively correlated with board independence. The tenure findings, in particular, are precisely what the Hermalin and Weisbach model would predict. Measures that indicate that the CEO has relatively less bargaining power, including outside director ownership, venture capital reputation, and the reputation of the firm's investment banker at the time of its IPO, are all positively correlated with board independence. Similarly, Baker and Gompers find that measures that reflect the CEO's bargaining power, including an estimate of the CEO's Shapley value and the reputation of the firm's venture capitalists, have the predicted signs (negative for the former and positive for the latter) with respect to the percentage of noninside directors on the board. At odds with the Hermalin and Weisbach model and unlike Boone et al., Baker and Gompers find a positive - albeit statistically insignificant - relationship between CEO tenure and percentage of non-inside directors. Finally, Ryan and Wiggins find that a CEO's pay becomes less linked to equity performance as his control over the board increases (proxied by his tenure and the proportion of insiders). These authors interpret these findings as consistent with the Hermalin and Weisbach bargaining framework, because

\footnotetext{
${ }^{14}$ Hermalin and Weisbach assume there is sufficient competition among potential replacement CEOs for the position that a replacement CEO has no bargaining power. Their model would be robust to giving a replacement CEO some bargaining power as long as it was less than that enjoyed by an incumbent CEO who is retained.
} 
it suggests that as CEOs become more powerful, they use this power to improve their well-being (e.g., as here, where this power allows them to reduce the volatility of their compensation).

\subsubsection{Assessment and Project Selection}

Dominguez-Martinez et al. (in press) is a similar model to Hermalin and Weisbach (1998); a key difference is that now it is the CEO who determines what information the board learns. An interpretation of Dominguez-Martinez et al.'s model is that there are two possible types of CEO, good and bad. In each of two productive periods, a CEO draws a project at random from a distribution of different projects (conditional on CEO ability, each period's draw is an independent event). Think of each project being summarized by its NPV. The difference between the two types of CEOs is that the distribution of projects (distribution of NPVs to be precise) is better for the good type than the bad type (e.g., the good type's distribution dominates the bad type's in the sense of first-order stochastic dominance).

The CEO sees the NPV "stamped" on the project he draws, whereas the board does not. In the second (final) period, the CEO's incentives are such that he implements the project he draws if and only if it has a positive NPV. In the first period, however, the CEO's incentives are possibly misaligned with that of the shareholders: The CEO values remaining in office in the second period. If his actions or performance lead the directors to infer he is the bad type and the board is not committed to retain him, then he will be dismissed as it is better to draw again from the pool of CEOs than to continue to the second period with a CEO who is known to be bad.

One potential solution would be for the board to commit to retain the firstperiod CEO for the second period. With that commitment, CEOs would choose only positive NPV projects in the first period. This, however, is not necessarily optimal because the directors are throwing away the option to replace the CEO if they infer he is likely to be bad. That is, as is also noted in Hermalin and Weisbach, the ability to replace a CEO a board infers is probably bad creates a valuable real option for the firm.

Given that good-type CEOs are more likely to have positive NPV projects than bad types, an alternative strategy for the board would be to commit to dismiss the CEO only if he doesn't undertake a project. This, however, is not without cost because now a CEO could be willing to undertake a negative NPV project if it is not so bad that the disutility resulting from pursing the project outweighs his utility from retaining his job. ${ }^{15}$ Under this governance rule, some number of negative NPV projects will be pursued.

A third strategy might be for the board to commit to keep the CEO only if he undertakes a positive NPV project. This might seem optimal, insofar as it avoids negative NPV projects and allows some learning, but could nevertheless

\footnotetext{
${ }^{15}$ Dominguez-Martinez et al. assume a CEO's first-period utility function is $\pi+\lambda \chi$, where $\pi$ is the returns from the first-period project, $\lambda>0$ is his benefit of keeping his job, and $\chi \in\{0,1\}$ indicates whether he loses or keeps his job, respectively.
} 


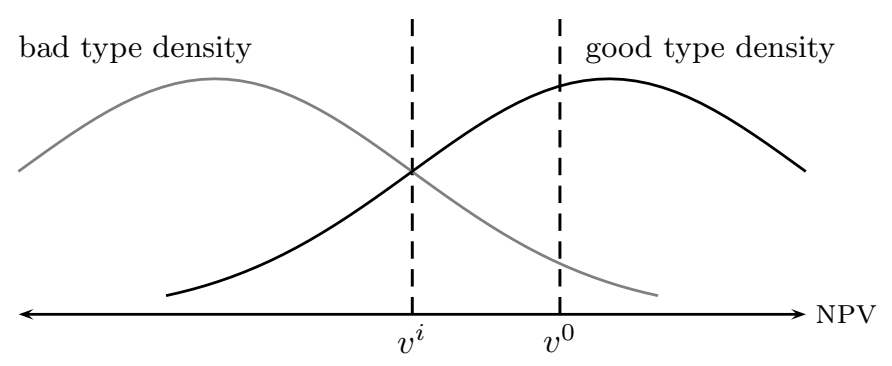

Figure 3: Illustration of the Dominguez-Martinez et al. (in press) model. The probability density functions over NPV are shown for the two types. From an informational perspective, the CEO should be retained if and only if the realized value of a project is above $v^{i}$. If, however, $v^{0}$ denotes the project with an NPV $=0$, then the board, to limit first-period loses, may wish to commit to retain the CEO if and only if realized value is above some cutoff strictly between $v^{i}$ and $v^{0}$.

be sub-optimal: How much is learned about the CEO's ability depends on the relative likelihood of the two types having projects with a particular NPV. It is possible, therefore, that if a given NPV is more likely from a good type than a bad type, then it could be worth having that project undertaken even if the NPV is negative because seeing the project provides valuable information about the CEO's ability. Conversely, if a given NPV is more likely from a bad type than a good type, then it could be worthwhile dismissing the CEO following the realization of the project even if its NPV is positive. Figure 3 illustrates. Purely from the perspective of optimal inference, the board should retain a CEO if he has a project with an NPV above $v^{i}$ and dismiss him otherwise. If, however $v^{i}<0=v^{0}$, then this cutoff implies first-period costs. Trading off these firstperiod costs against the value of information, the board may wish to set a cutoff, $v^{c}$, between $v^{i}$ and $v^{0}$; that is, a CEO keeps his job if and only if he undertakes a project and that project pays off at least $v^{c}$.

Dominguez-Martinez et al. observe that their model offers a possible explanation for why evidence of "poor decision making" does not always lead to CEO dismissal. Sometimes it is optimal to let a CEO pursue a bad strategy rather than stick to the status quo (i.e., better to pursue a negative NPV project rather than do nothing) because the information revealed from that course of action allows the board to update positively about the CEO's ability. Admittedly, as 
formulated here, the same model would also explain the dismissal of a CEO after moderate success if moderate success is more associated with low ability than high ability. ${ }^{16}$ Dominguez-Martinez et al.'s model also suggests an explanation for why new CEOs rarely seem to be riding with training wheels when it comes to managing their companies. Limiting a CEO's range of action, while perhaps a way to avoid risky mistakes, also limits how much the board can learn about his ability. Especially early in his career, when relatively little is known, the expected value of information can outweigh the expected cost of mistakes.

\subsubsection{Assessment and CEO Selection}

Hermalin (2005) is concerned with the fact that information is more valuable when a board is seeking to infer the ability of a relatively unknown CEO than that of a more established veteran. The reason is that the option to dismiss a poorly performing $\mathrm{CEO}$ is like a put option. Consequently, its value is greater, ceteris paribus, the greater is the amount of uncertainty. Hermalin builds on this insight to examine the relationship between a board's structure and its propensity to hire a new CEO from the outside (an external hire) versus from the inside (an internal hire). Presumably an internal hire is a better-known commodity than an external hire, meaning that an external hire offers the greater option value and is, therefore, more valuable ceteris paribus. How much more valuable, however, depends on the degree to which the board will monitor the CEO (its degree of diligence). Like the Hermalin and Weisbach (1998) model, the board makes a decision as to how intensively it will monitor the CEO, which is reflected in the probability it will get an additional signal correlated with his ability. ${ }^{17}$ Without the signal, there is no option value. Consequently, the value of uncertainty about a new CEO is greater the more diligent the board (i.e., the more likely it is to acquire the signal) and, therefore, a more diligent board is more willing to trade off other attributes for greater uncertainty than is a less diligent board. Hermalin argues that this insight offers an explanation for why there has been a growing trend towards both more external hires and shorter CEO tenures: Due to increased pressure from institutional shareholders, more government regulations, greater threats of litigation, and new exchange requirements, boards have become more independent and diligent. ${ }^{18}$ Hence, boards are more willing to monitor, which raises the likelihood they hire externally for the CEO position. ${ }^{19}$ More monitoring directly raises the likelihood of CEO dismissal and indirectly raises it if it leads firms to hire CEOs about whom less is known.

\footnotetext{
${ }^{16}$ Dominguez-Martinez et al. do not make this point. This is one of the ways our interpretation of their model could be said to differ from their actual model.

${ }^{17}$ Alternatively, and essentially equivalently, the signal is always observed, but its precision is an increasing function of the board's efforts at monitoring. See §VI of Hermalin.

${ }^{18}$ See Huson et al. (2001) and Gillan and Starks (2000) for evidence on trends toward greater board independence (technically, boards with a greater proportion of outside directors) and the rise of institutional investors.

${ }^{19}$ See Borokhovich et al. (1996), Huson et al. (2001), and Dahya et al. (2002) for evidence that the proportion of new CEO hires that are external has been increasing; the last provides evidence for this trend outside the Us.
} 


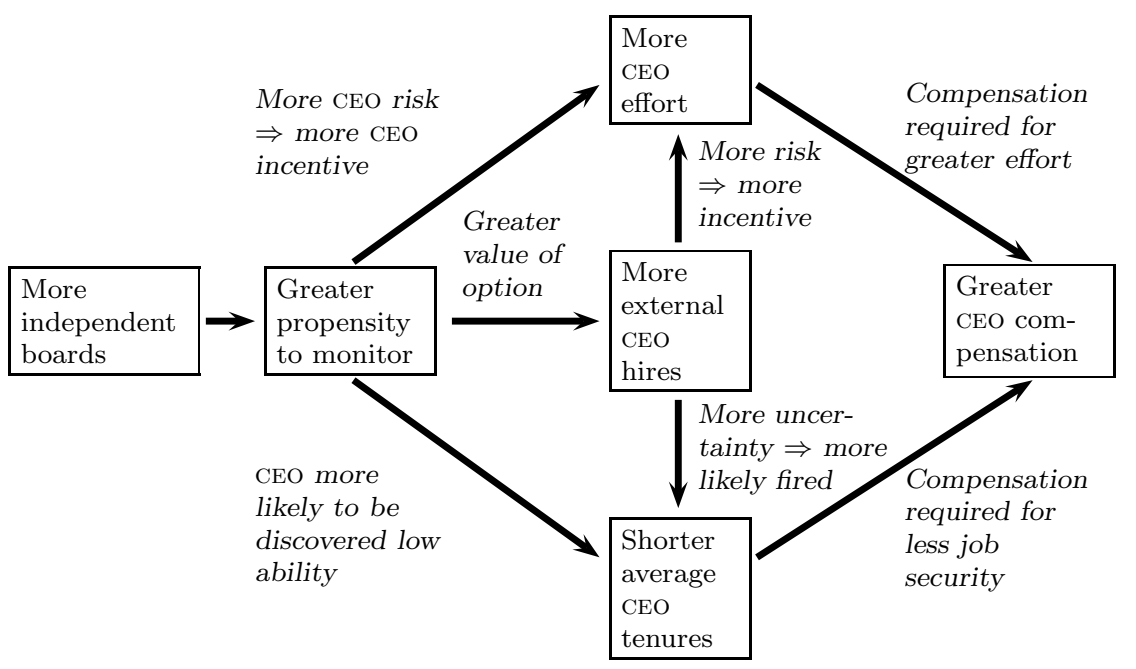

Figure 4: A graphical summary of the Hermalin (2005) model.

One response of CEOs to this greater monitoring pressure is for them to work "harder" (which could be interpreted as taking less perquisites). Both because they are led to work harder and their jobs are less secure, CEOs will demand greater pay in compensation. Hence, a consequence of more independent boards over time could be upward pressure on CEO compensation. ${ }^{20}$ Figure 4 summarizes Hermalin's model. ${ }^{21}$

\subsubsection{Other Assessment Models}

A number of other papers examine the mechanisms associated with the board's assessment of the CEO. Graziano and Luporini (2005) also has a board that

\footnotetext{
${ }^{20}$ As Hermalin notes, the positive correlation between board independence and CEO pay in time series need not imply a positive correlation in the cross section at any point in time. Hermalin sketches an extension of his model that would predict a negative correlation in cross section, despite a positive correlation over time. See his $\S \mathrm{V}$.

${ }^{21}$ It is worth noting that Hermalin is not the only theoretical explanation for the trend toward more external hires and greater CEO compensation. Murphy and Zábojník (2003, 2004) offer a non-boards-based model that takes as its main premise that there has been a decline in the value of managers' firm-specific knowledge relative to the value of their general knowledge. As they show, this will increase the willingness of firms to hire CEOs externally. Given Murphy and Zábojník's modeling of the CEO labor market, this greater willingness to go outside translates into a rise in CEO compensation. Hermalin discusses how his model can be extended to incorporate the Murphy and Zábojník model, see his §VI.
} 
seeks to determine CEO ability. Critical to their analysis is the presence of a large shareholder on the board, one who is willing to bear the cost of monitoring, but who also gains private benefits if the company pursues certain strategies (projects). Because only the large shareholder will monitor, they find there can be advantages to a dual-board system (e.g., as in much of continental Europe) because it may be advantageous to divorce the monitoring role from the power to have a say over the company's strategy. Hirshleifer and Thakor (1994) assume that boards always receive signals useful to assessing the CEO's ability, but boards differ insofar as some are lax and some are vigilant. Vigilant boards may choose to fire the CEO on the basis of a bad signal. The situation in Hirshleifer and Thakor is complicated by the possibility of a takeover bid by an outside party with independent information about the firm; consequently, it may behoove a vigilant board not to act on its own information, but wait to see what information can be learned by the presence (or not) of a takeover bid and the price bid. This article also exemplifies the fact that board governance is only one source of managerial discipline and, more specifically, it captures the notion that internal and external monitoring can serve as substitutes or complements. Warther (1998) is another article in which the board acquires information about managerial ability. Here, unlike the other models we've discussed, each director gets a private signal and aggregation of information is costly insofar as a director who indicates he received a negative signal is at risk of losing his board seat if he proves to be in the minority.

A recent strand of the literature has recognized that the board's monitoring of the CEO can create, in effect, a danger of opportunism or holdup by the board. ${ }^{22}$ The ability to dismiss the CEO after he has made firm-specific investments means the board can appropriate some of the CEO's returns, thereby diminishing his original investment incentives. Two papers in this strand are Almazan and Suarez (2003) and Laux (2008). In both, two critical assumptions are (i) initial contracts between board and CEO can be renegotiated and (ii) at least some kinds of boards (strong in Almazan and Suarez, independent in Laux) cannot commit to not behaving opportunistically or aggressively in renegotiation.

In Almazan and Suarez, after being hired, a CEO can, at personal cost, take a discrete action that raises, by a discrete amount, the probability that a given strategy or project will succeed. This action is observable by the board, but not verifiable, which creates an opportunity for later holdup. After the CEO takes (sinks) his action, a profitable opportunity for the firm may arise that requires a new CEO to exploit. If the board is strong enough to fire the incumbent CEO in favor of a new CEO, then the board can use that possibility to obtain salary concessions from the incumbent because losing his job means he loses a private benefit. The threat of being forced to make such concessions can undermine the CEO's initial incentive to take the costly action. To be more concrete, consider the following variation on Almazan and Suarez's idea: ${ }^{23}$ Suppose that the new

\footnotetext{
${ }^{22}$ Opportunism and holdup problems have been studied in a large number of areas of economics since Williamson $(1975,1976)$.

${ }^{23}$ The actual Almazan and Suarez (2003) model is more complex than what we present here.
} 
opportunity has the same expected payoff as keeping the incumbent CEO if he took the action and, thus, a higher expected payoff than keeping him if he didn't take the action. Suppose a weak board will never fire the CEO when the expected value of keeping him equals that of the new opportunity, but can fire him when the latter is greater. A strong board is always capable of firing the CEO. Assume it is possible, when the threat to dismiss the CEO is credible, for the board to capture, in renegotiation, the CEO's private benefit of control and push the CEO to some reservation utility (call it 0). Hence, a CEO with a strong board has no incentive to take the action: If the new opportunity doesn't arise, he retains his job no matter what he did, there is no renegotiation of his compensation, and he enjoys the control benefit. But if the new opportunity does arise he gets 0 regardless of his action; either he is fired, thus denied both pay and private benefit, or through renegotiation is forced down to a 0 reservation utility (payoff). Because his ultimate payoff is independent of his action, he has no incentive to incur the cost of taking it. The story is, however, different for a CEO who faces a weak board. Now, he is strictly better off if he has taken the action and the new opportunity arises: The board cannot threaten to fire him, so he continues to capture rents (wage plus private benefit). If he didn't take the action and the new opportunity arose, then he would lose both wage and private benefit. If the new opportunity arises with low frequency, so it is efficient for the incumbent CEO to take the action, then having a weak board will be better than having a strong board.

In Almazan and Suarez, the distinction between strong and weak boards is a distinction about their bargaining power. In Laux (2008), the board always has all the bargaining power at the renegotiation stage (can make a take-itor-leave-it offer to the CEO), but boards differ in their degree of independence. This variation in degree of independence acts, however, like a shift in bargaining power. Consequently, for reasons similar to those in Almazan and Suarez, a firm can be better off with a less independent board than a more independent board.

\subsubsection{Additional Empirical Analyses of Assessment}

There is both anecdotal and statistical evidence that boards dismiss poorly performing CEOs. Based on interviews, Mace (1971) and Vancil (1987) conclude that boards fire, albeit often reluctantly, poorly performing CEOs. There are numerous statistical analyses that show poor performance, measured either as stock returns or accounting profits, positively predicts a change in the CEO. ${ }^{24}$ Simply documenting a relationship between poor performance and an

While those complications lead to a richer and more nuanced analysis, they are not necessary to get the basic idea across.

${ }^{24} \mathrm{~A}$ problem facing empirical work is that firms often offer a face-saving rationale for a change in CEO (e.g., he wishes to spend more time with his family) rather than admit the CEO was forced out for doing a bad job. See Warner et al. (1988), Weisbach (1988), Parrino (1997), and Jenter and Kanaan (2008) for further discussions of this issue and strategies for dealing with it. To the extent non-performance-based CEO turnover is random, it simply adds noise to turnover regressions, thus reducing the power of such tests, but leaves them unbiased and consistent. 
increased probability of a $\mathrm{CEO}$ turnover, although suggestive of board monitoring, is nonetheless far from conclusive. After all, a sense of failure or pressure from shareholders could explain this relationship. To better identify the role played by the board, Weisbach (1988) interacts board composition and firm performance in a CEO turnover equation. His results indicate that when boards are dominated by outside directors, CEO turnover is more sensitive to firm performance than it is in firms with insider-dominated boards. ${ }^{25}$ This result is consistent with the predictions of Hermalin and Weisbach (1998) and Laux (2008) under the presumption that outsider domination is a good proxy for board independence.

Yermack (1996) also seeks to relate board structure to CEO turnover. Instead of an interaction between board composition and performance, Yermack interacts the log of board size with financial performance and finds a positive and significant coefficient on this interaction term. ${ }^{26}$ That the coefficient is positive indicates that firms with smaller boards have a stronger relationship between poor performance and CEO turnover than do firms with larger boards. This finding is consistent with the oft-heard view that smaller boards are more vigilant overseers of the CEO than larger boards. In particular, in response to poor performance, they may not be paralyzed by free-riding or otherwise plagued with inertia in the way that larger boards are.

Another of Yermack's findings (supported by later work by Eisenberg et al., 1998 ) is that board size and firm performance, the latter measured by average Tobin's $Q$, are negatively correlated. ${ }^{27}$ It is not obvious how to reconcile Yermack's results with the renegotiation-based models discussed previously: These models suggest that too vigilant (here, small) a board is detrimental to a firm insofar as it discourages the CEO from taking valuable actions or means such actions can be implemented only at greater cost. Yermack's findings could also be at odds with Hermalin and Weisbach's (1998) bargaining-based model: If larger boards are less vigilant - effectively less independent - then the logic of the Hermalin and Weisbach model suggests a successful CEO will bargain to increase the size of his board. This would yield a prediction consistent with Yermack's interaction effect: Larger boards will be less responsive to a signal of poor performance than smaller boards. However, because it is the more successful CEOs who have the larger boards, the Hermalin and Weisbach model would seem to predict that firms with larger boards would outperform those

\footnotetext{
${ }^{25}$ Dahya et al. (2002) find a similar result in the UK: Firms that adopted the recommendations of the Cadbury Commission show a greater sensitivity of CEO turnover to performance than non-adopting firms. Related, Goyal and Park (2002) find that the sensitivity of CEO turnover to performance is less when the CEO also serves as board chair. Adams and Ferreira (2008b) find that the proportion of women on boards increases the CEO performance-turnover sensitivity even after controlling for the proportion of outside directors, which suggests that the proportion of female outside directors - directors outside of the "old-boy network" - is proxying for board independence.

${ }^{26}$ See Faleye (2003) for a similar study.

${ }^{27}$ Average Tobin's $Q$ is the ratio of the market value of assets to their book value. A presumption in the literature is that $Q>1$ is partially a reflection of the good job management is doing. As long as one controls for book value of assets, Tobin's $Q$ regressions are similar to market-value regressions.
} 
with smaller boards, which is contrary to Yermack's findings.

Such issues led Coles et al. (2008) to reestimate Yermack, but with greater attention to heterogeneity issues. Consistent with the spirit of Figure 2 and the conceptual framework set forth there, Coles et al. seek to control for the possibility that boards have different sizes because firms face different problems. In contrast to Yermack's findings, Coles et al. find that firm performance (average Tobin's $Q$ ) is increasing in board size for certain types of firms, namely those that are highly diversified or that are high-debt firms.

Perry (1999) breaks down the cross-sectional relationship between CEO turnover and firm performance by whether the outside directors are paid using incentives. He finds that the relationship between CEO turnover and firm performance is stronger when boards have incentives. This finding suggests that providing explicit incentives to directors leads them to be more vigilant (act more independently). Beyond incentive reasons, another potential explanation is the following: In firms that make use of incentive pay for directors, the directors have a professional rather than a personal relationship with the CEO and, thus, are relatively independent of him.

\subsection{Setting of Strategy}

In addition to making decisions concerning the hiring and firing of CEOs, boards may also be involved in the setting of strategy or, somewhat equivalently, the selection of projects. Certainly surveys of directors - see the discussion of Demb and Neubauer (1992) above - indicate that directors believe themselves to be involved in setting strategy.

\subsubsection{Theory}

To an extent, many of the models discussed above could be modified to make them about boards' oversight of strategy. Instead of replacing the CEO, the board compels him to change strategy. In an adaptation of Almazan and Suarez (2003) or Hermalin and Weisbach (1998), the CEO could be assumed to have an intrinsic preference for the incumbent strategy versus a replacement (the incumbent strategy provides, e.g., more opportunity to consume perquisites). In an adaptation of Laux (2008), similar results would follow if one assumed the financial returns to the replacement strategy are independent of the CEO's initial actions.

An alternative modeling approach is to investigate the choice of strategy as a game of information transmission: the CEO (or management more generally) has different preferences than the board concerning projects (strategies). A number of observers are coming to the view that information transmission between the board and the $\mathrm{CEO}$ is important for good governance (see, e.g., Holmstrom, 2005). This is particular true when the CEO has payoff-relevant private information, insofar as an agency problem arises because the CEO can influence the board's decision his way through the strategic release of information. 
Adams and Ferreira (2007) build a model based on four broad assumptions: (i) the CEO dislikes limits on his actions (loss of control); (ii) advice from the board raises firm value without limiting a CEO's actions; (iii) the effectiveness of the board's control and the value of its advice are better the more informed the board is; and (iv) the board depends crucially on the CEO for firm-specific information. In the Adams and Ferreira model, the board can learn the amount, $a \in[0,1]$, by which a project should be optimally adjusted (e.g., what the appropriate level of investment in it should be). The board can do this, however, only if the CEO has informed them about the project. It is assumed the CEO can withhold that information, but if he chooses to share it, then he must do so honestly (i.e., using the standard terminology of the contracts literature, the information is "hard"). The CEO has a bias, $b>0$, such that he likes to increase the size of projects (e.g., invest more than is appropriate).$^{28}$ Ignoring fixed terms and additively separable aspects of their respective utilities, the utility of the board and CEO as a function of the size of the project, $s$, and the true $a$ are quadratic losses,

$$
U_{B}=-(s-a)^{2} \text { and } U_{C}=-(s-a-b)^{2},
$$

respectively. The board's knowledge of $a$ is its private information. The board can, however, send a message $m \in[0,1]$ as to what its value is. Unlike the CEO's information, the board's information is "soft," in that a false message (i.e., $m \neq a$ ) can be sent. Provided the CEO has the power to choose $s$ and the board has learned $a$, the message-transmission subgame is a cheap-talk game (Crawford and Sobel, 1982). This subgame has multiple equilibria, but one is maximally - although not fully - revealing of the board's information.

Observe that $s \neq a$ (at least almost surely) because of the CEO's bias and the imperfection of information transmission in equilibrium. This provides the board with a motive to assert control; that is, take the choice of $s$ out of the CEO's hands. Suppose the board could always take control. Observe it would, then, be in the CEO's interest to have always informed it about the project. Absent that information, the board would set $s=\mu_{a}$, where $\mu_{a}=\mathbb{E}\{a\}$. The CEO's payoff would be a concave function of the random variable $\mu_{a}-a-b$, which has an expected value of $-b$. With the CEO's information, the board would set $s=a$. The CEO's payoff would be a concave function of the constant, $-b$. Since the former scenario is a mean-preserving spread of the second, it follows that CEO will prefer the second; that is, revealing his information.

To generate further tension between the board and the CEO, Adams and Ferreira assume the CEO suffers a personal loss, $\ell>0$, if control is taken from him. Further, they assume the board is not necessarily assured of being able to seize control. Rather, the board chooses the probability, $\pi$, that will seize control. The board incurs a cost that is increasing in $\pi$. The marginal cost of $\pi$ is, however, falling in the board's level of independence. The rationale for this last assumption is that more independent boards find it easier to confront

\footnotetext{
${ }^{28}$ Alternatively, one could assume he likes to economize on effort, so prefers smaller projects; in this case, $b<0$. The critical assumption is that $b \neq 0$.
} 
the CEO than less independent boards. Under Adams and Ferreira's maintained assumptions, it is never optimal for the board to choose $\pi=1$. Critically, the board chooses $\pi$ after the CEO has or has not revealed his information. Moreover, because the value of seizing control is greater when the board can set $s=a$ rather than just $=\mu_{a}$, the board will choose a greater value of $\pi$ when it has been informed by the CEO than when it hasn't. Consequently, the CEO now has incentive to withhold his information: by withholding it, he raises the probability he retains control (avoids losing $\ell$ ).

If the board is sufficiently lacking in independence, then the probability of its seizing control, even if the CEO reveals his information, is low. In fact, it can be so low that the CEO is willing to run the increased risk of losing control that follows his revealing his information in order to gain the board's advice (i.e., the informative message $m$ ), because the advice will help him reduce his expected quadratic loss. Adams and Ferreira show that there can exist an interior equilibrium in which, provided the board's independence is below a cutoff, the CEO indeed reveals his information. Conditional on the board's independence being at or below the cutoff, the firm's expected profits are greatest if the board's independence equals the cutoff. At this level of independence, the expected gain from being able to utilize the board's information outweighs the expected loss from the size of the project sometimes being distorted (i.e., in those states when the CEO retains control). The Adams and Ferreira model also implies that it may be optimal to separate the advisory and monitoring roles of the board; that is, to have a dual board system as in many countries in Europe.

Harris and Raviv (in press) is similar in spirit to Adams and Ferreira. Harris and Raviv assume that the CEO and the insider directors, like the outside directors in Adams and Ferreira, have information relevant to the quadratic loss. The payoffs, net of fixed terms and additively separable aspects of their respective utilities, are

$$
U_{O}=-\left(s-a_{O}-a_{I}\right)^{2} \text { and } U_{I}=-\left(s-a_{O}-a_{I}-b\right)^{2},
$$

where the subscripts $O$ and $I$ denote outsiders and insiders, respectively, and $a_{t}$ is the information that the $t$ group of directors have about the optimal size of the project. Observe, now, that the optimal size from the shareholders' perspective is $s=a_{O}+a_{I}$. The value of $a_{t}$ is the private information of the $t$ group of directors. Unlike in Adams and Ferreira, now it could be suboptimal, from the shareholders' perspective, to give control over $s$ to the outsiders: although the insiders will almost surely not choose the optimal $s$ given control, they might get closer if their information is particularly valuable (i.e., the variance of $a_{I}$ is relatively big). Harris and Raviv consider two board structures: outsider control and insider control. When group $t$ has control, it has the choice of choosing $s$ or delegating the choice to the other group. When group $t$ makes the choice it receives a message from the other group about that other group's information. As in Adams and Ferreira, the equilibria of these cheap-talk games do not permit full information revelation. When the insiders' information is sufficiently valuable relative to the outsiders' (i.e., $\operatorname{Var}\left(a_{I}\right) / \operatorname{Var}\left(a_{O}\right) \geq \kappa>1$, 
$\kappa$ a constant that depends on parameter values) and information is valuable relative to the agency problem (specifically, $\operatorname{Var}\left(a_{I}\right) / b^{2} \geq \omega>1, \omega$ a constant that depends on parameter values), then insider control is superior to outsider control. If those conditions aren't met, then outsider control is superior.

Like Adams and Ferreira and Harris and Raviv, Raheja (2005) wishes to understand board structure in the light of the board's need to obtain information about the firm's projects or strategies. Unlike Adams and Ferreira, where all board members are equally ignorant, or Harris and Raviv, where both inside and outside directors respectively have private information, Raheja assumes that only the inside directors possess private information. In contrast to most of the literature, Raheja departs from the idea that the non-CEO inside directors and the CEO have coincident incentives. Insiders control the CEO through the threat of "ratting" him out to the outsiders, who will then join with the insiders in firing the CEO, should the CEO misbehave.

Although a clever model, it is difficult to reconcile Raheja's model with the evidence in Mace (1971) or Vancil (1987). Insubordination by a CEO's management team seems exceedingly rare. Moreover, what evidence there is about whistle-blowers (rats) is hardly encouraging for Raheja's model. Anecdotal evidence, at least, suggests that whistle-blowers tend to suffer, more than be rewarded, for their actions (see, e.g., Lublin, 2002). Evidence of whistle-blowers going to outside directors is rare - the most prominent recent whistle-blower, Enron's Sherron Watkins, for instance went to the CEO (Ken Lay) with her concerns.

Song and Thakor (2006) also consider information transmission relevant to project selection. Like some other work in this area, they build on the careerconcerns notions of Holmstrom (1999). Unlike previous work, they assume that both the board and the CEO have career concerns. Unlike Holmstrom, who assumes all actors are equally ignorant about theirs and others' abilities, Song and Thakor assume that both the CEO and board each know their own abilities. In the Song and Thakor model, CEO ability means how likely the CEO is to identify a project to undertake; whereas board ability means how accurate the board is at assessing the value of any project put forth by the CEO. Independent of his ability, the CEO also obtains a signal of a project's quality, which he can pass along truthfully or not to the board. Song and Thakor show that when the probability of good projects is low, then the board will be biased toward underinvestment. If the probability of good projects is high, however, then the board will be biased toward overinvesting. Song and Thakor suggest that the probability of good projects will be low during economic downturns and high during economic booms, which means their model offers an explanation of changes in governance over the business cycle: during downturns, the board will be tougher and, during upturns, the board will be more lenient.

The Song and Thakor model is rather complex, with many moving parts. To provide some intuition for its results, consider an adaptation of Hermalin and Weisbach (2008) motivated by Song and Thakor. Assume a risk-averse CEO with career concerns à la Holmstrom (1999). Assume his ability, unknown ex ante to all, is $\alpha \sim N(0,1 / \tau)$, where $N\left(\mu, \sigma^{2}\right)$ denotes a normal distribution with 
mean $\mu$ and variance $\sigma^{2} .^{29}$ A project arises that will payoff $r+\alpha+\varepsilon$, where $r$ is a known constant reflecting the current economic environment and $\varepsilon \sim N\left(0, \sigma_{\varepsilon}^{2}\right)$. A public signal, $s$, about the CEO's ability is realized after the project arises, but before the board must commit to the project. Assume $s \sim N(\alpha, 1 / q)$, where $q$ is a measure of the board's quality. Note the unconditional distribution of $s$ is $N(0,1 / H)$, where $1 / H=1 / \tau+1 / q$. Normalize the firm's revenues if the board decides not to pursue the project to be 0 . Using the standard formula for forming posteriors from normal distributions (see, e.g., DeGroot, 1970, p. 167), the expected value of the project conditional on the signal is

$$
r+\frac{q s}{q+\tau}
$$

The board proceeds with the project if that is positive; that is, if

$$
s \geq-\frac{(q+\tau) r}{q} \equiv S \text {. }
$$

Given the option of blocking a negative NPV project, the firm's expected value prior to the reception of the signal is

$$
\begin{aligned}
V & =\int_{-\infty}^{\infty} \max \left\{0, r+\frac{q s}{q+\tau}\right\} \sqrt{\frac{H}{2 \pi}} \exp \left(-\frac{H}{2} s^{2}\right) d s-w \\
& =\frac{\sqrt{H}}{\tau} \phi(S \sqrt{H})+(1-\Phi(S \sqrt{H})) r-w,
\end{aligned}
$$

where $w$ is the CEO's compensation, $\phi(\cdot)$ is the density function of a standard normal random variable (i.e., with mean zero and variance one), and $\Phi(\cdot)$ is the corresponding distribution function.

Differentiating $V$ with respect to $q$, it is readily shown that the firm's expected value, $V$, is increasing in the quality of the board, $q$, all else held equal. Intuitively, the ability to block a bad project creates an option. An option that is never exercised is worthless; hence, if the signal were complete noise, as would be the case if board had zero quality (recall the signal's variance is $1 / q$ ), there would be effectively no option. As the quality of the board and, thus, information improves, the more valuable this option becomes and, therefore, the more valuable the firm becomes.

It is not, however, costless to increase board quality without bound. First, it seems reasonable that higher quality directors command a premium or that providing a board with sufficient incentives to do a high-quality job is expensive. So the cost of board quality is increasing in quality. Under suitable assumptions about this cost function (e.g., that marginal cost be rising in $q$ ), there will be an optimal finite value for $q$. In addition, if the CEO labor market reacts to the signal so that the CEO's future salary is an increasing function of the signal, then the CEO is exposed to more future salary risk the more informative the signal is (i.e., the greater is $q$ ). Intuitively, the posterior estimate of the CEO's

${ }^{29}$ While the realization of $\alpha$ is unknown by anyone, all distributions are common knowledge. 
ability is a weighted average of the prior, which is fixed, and the signal, which is noisy. The more informative the signal is known to be, the more weight is assigned the signal. This increases the CEO's risk more than the lower variance of the signal itself reduces it (see Hermalin and Weisbach, 2008, for details). A CEO will require compensation for this greater risk, so his initial salary $(w$ in expression (1)) will have to be greater. In light of this cost, under suitable conditions, it will again be the case that a finite $q$ is optimal.

From expression (1), the marginal net return to $q$ is

$$
\frac{1}{2 \tau q^{2}} \phi\left(\frac{-r \tau}{\sqrt{H}}\right) H^{3 / 2}-\frac{\partial w}{\partial q}
$$

(note $S \sqrt{H}=-r \tau / \sqrt{H}$ ). The change in the marginal net return to $q$ with respect to $r$, the measure of the current economic environment, has the same sign as

$$
\frac{d}{d r} \phi\left(\frac{-r \tau}{\sqrt{H}}\right)<0 ;
$$

where the inequality follows because an increase in $r$ is a move further into the left tail of the density. Therefore, the marginal net return to $q$ is falling in $r$, which means that the optimal quality of the board is lower when economic conditions are good (i.e., $r$ is high) than when they are bad (i.e., $r$ is low). Intuitively, when times are good, the board will wish to let mediocre CEOs go ahead with projects, but they won't when times are bad. Consequently, the value of improving the monitoring of projects is greater when times are bad than when they are good.

Baranchuk and Dybvig (in press) is an interesting article in this area because it is not worried about information transmission between CEO and board, but among the various board members themselves (which, in practice, includes the CEO). Each director $i$ has a belief, $\mathbf{a}_{i} \in \mathbb{R}^{n}$, as to what the firm should do. Similar to Adams and Ferreira (2007) and Harris and Raviv (in press), a director expects to suffer a quadratic loss in the distance between his beliefs as to what the firm should do and what the firm's actual course of action, $\hat{\mathbf{a}}$, is; that is, a director's utility is

$$
-\left\|\mathbf{a}_{i}-\hat{\mathbf{a}}\right\| .
$$

The directors arrive at $\mathbf{a}$ according to a solution concept that the authors call consensus. This solution concept has many desirable properties, including existence for all such games. A weakness of the concept, however, is that there is no explicit extensive-form game to which it is a solution (consensus is a cooperative game-theoretic concept). Another issue is there is no scope for directors to update their beliefs based on what they learn of others' beliefs. Absent biases on the part of the directors, it is not clear why the directors would not freely share their information and arrive at a consensus belief, which in turn would lead to a unanimous choice as to what the firm should do.

By the revelation principle, the information-transmission models discussed here could all be solved by a direct-revelation mechanism if complete contract- 
ing were possible. ${ }^{30}$ That is, if the parties could fully commit and monetary transfers of any level among them were feasible, then the parties could achieve an informationally constrained optimum via contracting. There would, therefore, be no need to worry about board composition or control. Hence, as is common of many models seeking to explain the institutions we observe, there is a reliance, at some level, on the assumption that contracting is necessarily incomplete. In particular, either boards cannot commit fully as to how they will use the information revealed to them or it is infeasible contractually for them to pay the CEO (or others) in a manner sufficient to induce efficient revelation. For instance, in Harris and Raviv (in press), a direct-revelation mechanism would do better than the equilibrium outcomes considered provided that the parties could contract directly on the size of the project as a function of their announcements and they could make transfers. Although this literature tends not to explore fully why contracts are incomplete, casual empiricism would suggest that there are, indeed, limits to both commitments and transfers. So, realistically, organizations are necessarily in a second- or third-best situation. Consequently, the "law of the second best" often applies - to remedy, in part, the second- or thirdbest problem, the parties can gain by introducing another, partially offsetting problem. ${ }^{31}$ In the literature on boards, the offsetting "problem" is having a less diligent/less controlling/less independent board. Having a "lax" board is a way of partially committing to how information will be used, thereby mimicking, in part, the commitment that a contractual solution, were one feasible, would provide.

\subsubsection{Empirical and Experimental Evidence}

Gillette et al. (2003, 2008) perform a series of interesting experiments designed to get at the issue of information transmission within the boardroom. In Gillette et al. (2003), they consider a laboratory setting in which informed insiders are grouped with uninformed outsiders in a simulated boardroom setting. They find that the inclusion of outsiders improves welfare, by making undesirable equilibria less likely. Gillette et al. (2008) compare, again in a laboratory setting, single-tiered boards, two-tiered boards, insider-controlled boards, and outsider controlled boards. They find that two-tiered boards tend to be overly conservative in their choices and that outsider-controlled boards tend to lead to the most efficient payoffs.

The class of models based on strategic information transfer implicitly relies on the assumption that outsider directors are less well informed than are inside directors. Ravina and Sapienza (in press) adopt a clever approach to testing this assumption. These authors examine the relative profitability of trades in their companies' stocks made by outsiders and insiders and find that both types

\footnotetext{
${ }^{30}$ Note Song and Thakor is not an information-transmission model.

${ }^{31}$ An example of the law of the second best is, for instance, encouraging some degree of cartelization of a polluting industry: By reducing competition, price will be driven above private marginal cost; hence, society may hope to get price closer to social marginal cost (i.e., cost inclusive of the negative externality caused by the pollution).
} 
of directors earn abnormal profits, but that insiders earn better returns than do outsiders. These results suggest that both types of directors have access to inside information but that outsiders information is strictly worse than insiders'. Thus the finding supports the underlying assumption of the information-based models of boards.

\section{How are boards of directors structured?}

We have discussed some explanations for why there are boards, and why one might expect endogenously-chosen boards to provide monitoring of management, despite the fact that management typically has some say over the board's composition. But the theories simply provide a stylized description of the underlying tensions in the role of the board in corporate governance. Actual governance is much richer than these bare-bones characterizations.

There are a number of questions that can only be answered by looking at data on real-world boards of directors. How are boards structured in practice? Does this structure coincide with the earlier-discussed theories? How has it changed over time, both in response to changes in the economy and regulatory environments?

\subsection{Some Facts}

Observers typically divide directors into two groups: inside directors and outside directors. Generally, a director who is a full-time employee of the firm in question is deemed to be an inside director, while a director whose primary employment is not with the firm is deemed to be an outside director. Outside directors are often taken to be independent directors, yet the independence of some directors who meet the definition of an outsider is questionable. Examples of such directors are lawyers or bankers who do business with the company. Outsiders of dubious independence are sometimes put in a third category in empirical work (see, e.g., Hermalin and Weisbach, 1988): "affiliated" or "gray" directors. In recent years, public pressure and regulatory requirements have led firms to have majorityoutsider boards.

The characteristics of boards of large U.S. corporations have been described in a number of studies. For example, Fich and Shivdasani (2006) consider a sample of 508 of the largest US corporations between 1989 and 1995. They find that, on average, outsiders make up $55 \%$ of directors, insiders $30 \%$, and affiliated directors the remaining $15 \%$. The average board contains twelve directors, each receiving approximately $\$ 36,000$ in fees (plus stock options), and has 7.5 meetings a year. A number of the directors served on multiple boards; the outside directors in these firms averaged over three directorships. While these data are for large public firms, Linck et al. (2008) consider a larger sample of 8000 (necessarily) smaller firms, with similar patterns in the data.

While the existence and basic structure of boards have remained relatively constant over time, the way in which they are composed has changed. Lehn et al. 
(in press) consider a sample of 81 firms that have survived as public companies from 1935 until 2000. Survivorship bias complicates the interpretation of their findings, nevertheless they reflect some basic trends that have affected boards. First, board size appears to have a hump pattern over time; it averages 11 in 1935, peaks at 15 in 1960 and declines to 11 in 2000. However, board size has become more uniform over time as the standard deviation of board size drops from 5.5 in 1935 to 2.7 in 2000. These companies' boards have become more outsider-dominated as well; insider representation drops from $43 \%$ in 1935 to just $13 \%$ in 2000. Part of this drop can be explained by the typical life cycle of firms. As founding families exit and firms become more professionally managed, agency problems can become worse as those in control are no longer significant owners. In response, firms will wish to add outside directors to counteract the increased agency problems.

Since 2000, there have been significant changes. Sarbanes-Oxley contained a number of requirements that increased the workload of and the demand for outside directors (see Linck et al. (in press) for a description of these requirements). In addition, the scandals at Enron and Worldcom have led to substantially increased public scrutiny of corporate governance. Consequently, boards have become larger, more independent, have more committees, meet more often, and generally have more responsibility and risk (again see Linck et al., in press). These changes both increased the demand for directors and decreased the willingness of directors to serve for a given price. It is not surprising, therefore, that director pay and liability insurance premiums have increased substantially. From the shareholders' perspective, the net effect of this regulation is not clear; future research will need to address the extent to which the additional monitoring offsets the incremental costs imposed by Sarbanes-Oxley.

\subsection{Factors in Board Composition that Potentially Affect a Board's Actions}

We have already discussed much of the literature relating board composition (in terms of the insider-to-outsider ratio) and board size to board actions regarding oversight of the CEO, as well as to overall firm performance (see section 2.2). Yet beyond the insider-to-outside ratio and board size, other board attributes no doubt play a role. Each board of directors is likely to have its own dynamics, a function of many factors including the personalities and relationships among the directors, their backgrounds and skills, and their incentives and connections. Some of these factors are readily measured while others are not. There has been considerable research that seeks to estimate the impact of various board characteristics on board conduct and firm performance.

\subsubsection{CEO-Chairman Duality}

Many CEOs also hold the title of Chairman of the Board; this duality holds in almost of $80 \%$ of large us firms (see Rechner and Dalton, 1991). This structure is viewed by many as giving CEOs greater control at the expense of other parties, 
including outside directors. To mitigate the consequent problems, many observers of corporate governance have called for a prohibition on the CEO serving as chairman (see, e.g., Jensen, 1993).

A number of recent papers have examined the use of dual titles in corporate governance empirically. Brickley et al. (1997) considers the performance effects of combined titles. These authors find little evidence that combining or separating titles affects corporate performance. They conclude that the separation and combination of titles is part of the natural succession process described by Vancil (1987). In contrast, Goyal and Park (2002) find that the sensitivity of CEO turnover to performance is lower when titles are combined, consistent with the notion that the combination of titles is associated with increased power over the board. Similarly, Adams et al. (2005) find evidence consistent with the view that CEOs also holding the chairman title appear to hold greater influence over corporate decision-making.

Overall, these studies are consistent with the view that combined titles are associated with CEOs having more influence in the firm. However, this relation is not necessarily causal. Influence inside an organization arises endogenously, and with influence, generally come fancier titles. The Goyal and Park and Adams et al. findings potentially reflect CEO power that came about endogenously through a manner similar to that described in the Hermalin and Weisbach (1998) model. In other words, a CEO who performs well would be rewarded by his being given the chairman title as well. Such a process, especially if the increase in power arises because of a demonstrated high ability, would not necessarily imply performance changes following shifts in titles, consistent with the Brickley et al. findings.

Even if it is true that combining the titles of CEO and chairman means that an individual has, on average more influence over his firm, it does not follow that mandating separate titles would improve corporate performance. In fact, Adams et al. - similar to Brickley et al. - find that measures of CEO power are not systematically related to firm performance. This is consistent with our overarching argument that actual corporate-governance practice needs to be seen as part of the solution to the constrained optimization program that is corporategovernance design. Hence, imposing separate titles would either yield a less optimal solution or lead to a, possibly inefficient, work-around that maintained the optimal amount of CEO power. ${ }^{32}$ Moreover, as noted earlier, making the CEO's job worse likely means an offsetting increase in pay as compensation. Consequently, as with most policy prescriptions in the area of governance, policy makers should be wary of calls for prohibiting the CEO serving as chairman.

\subsubsection{Staggered Boards}

A common, yet controversial, governance arrangement is known as "staggered boards." When a firm has a staggered board, instead of holding annual elections

\footnotetext{
${ }^{32}$ Recall that, in a number of models of boards, ceding some control to management is optimal (see e.g., Almazan and Suarez, 2003, Laux, 2008, Adams and Ferreira, 2007, and Harris and Raviv, in press).
} 
for each director, directors are elected for multiple years at a time (usually three), and only a fraction (usually a third) of the directors are elected in a given year. This practice is typically adopted as a way of shielding a firm from takeover because a potential acquirer cannot quickly take control of the firm's board even it controls $100 \%$ of the votes. This arrangement is more common that one might imagine - in the Faleye (2007) sample, roughly half of the firms have classified (staggered) boards.

While the consequence of the separation of the CEO and chairman positions on firm performance is ambiguous, less ambiguity exists with respect to staggered boards; the empirical evidence indicates this arrangement is not in the shareholders' interests (although, as with much of the empirical work, caution is warranted due to joint-endogeneity issues). Both Jarrell and Poulsen (1987) and Mahoney and Mahoney (1993) find negative returns when firms announce they are classifying their boards (although Jarrell and Poulsen's finding is not statistically significant). Bebchuk et al. (2002) find that a classified board almost doubles the odds that a firm remains independent when faced with a hostile takeover. Because some would-be acquirers are no doubt scared off by the staggered board, the Bebchuk et al. findings likely underestimate the ability of a classified board to resist takeovers. Bebchuk and Cohen (2005) find that firms with staggered boards have lower value than other firms, using Tobin's $Q$ as a measure of value. Finally, Faleye (2007) finds that a staggered board lowers the sensitivity of CEO turnover to firm performance.

An implication of the view that staggered boards entrench managers and decrease value is that when firms "de-stagger," return to annual elections for all directors, value should increase. Guo et al. (2008) consider a sample of firms that de-stagger and find that the value of these firms does, in fact, increase. They also find that de-staggering is not typically initiated by managers, but by activist shareholders. Subsequent to the de-staggering, investor reaction indicates that these firms are more likely to be takeover targets. All of these findings reinforce the view that staggering boards is a mechanism that serves to protect management by making takeovers difficult.

All in all, it appears that firms with staggered boards do worse than firms with annual board elections. Of course, some of this effect could be due to endogeneity; firms with already entrenched managers are more likely to be able to convince shareholders to adopt staggered boards. Or, to take a less sinister view, those managers who prove themselves are in a position to bargain for greater job security as part of an optimal (second-best) bargain for their continued service (and those who fail to prove themselves become vulnerable to de-staggering and takeover). In this light, stock-market reaction to announcements about whether the board will be staggered or not could be due to the news such announcements convey vis-à-vis the bargaining toughness and independence of the board rather than to simply whether the board is or isn't staggered. 


\subsection{The Role of Particular Types of Outside Directors}

To be considered an outsider, a director's primary employment must be with a different organization than the firm on whose board he serves. Outside directors typically have backgrounds that will enable them to be valuable to a board, or to represent an important constituency. A small literature considers particular types of directors and their specific roles in corporate governance.

\subsubsection{Bankers}

Many firms have bankers on their boards. Bankers may be added to boards both because they can monitor the firm for the lender for whom they work and because they can provide financial expertise. Both Booth and Deli (1996) and Byrd and Mizruchi (2005) consider the extent to which bankers play a monitoring role. These authors find that, when a director is affliated with a bank lending to the firm, the firm's overall debt ratio is lower. This finding is consistent with a view that such an affiliated director can protect the bank's interest by discouraging the firm from taking out loans from other banks that could increase the risk to the director's bank. Güner et al. (in press) find evidence suggesting that adding commercial bankers to boards increases a firm's ability to access debt markets, but that the firms that utilize this increased financial flexibility the most are those firms with good credit but poor investment opportunities. Güner et al. argue that having bankers on boards can be a double-edged sword, in that the bankers can improve a firm's access to capital markets, but sometimes this improved access works to the benefit of the bank rather than the firm doing the borrowing.

\subsubsection{Venture Capitalists}

Many firms are founded with funding from venture capitalists. As a condition of receiving funding, new enterprises must yield some degree of control to the venture capitalists. Venture capitalists have a fiduciary responsibility to their own investors to exit these enterprises relatively quickly, and generally leave these enterprises' boards when they sell their ownership stake in them. Despite the shortness of VCs' tenures as directors, a study by Baker and Gompers (2003) suggests that their presence can affect firms long after they have left the board. Baker and Gompers find that the initial presence of a venture capital investor, especially one with a strong reputation, is likely to decrease the CEO's bargaining power relative to the board. Empirically, a high-reputation venture capitalist leads to a more powerful board, even after the venture capitalist exits his investment. The interpretation of this result is that such a venture capitalist negotiates substantially more control rights than is typical for outside investors in other private firms. When these firms go public, this balance of power away from management tends to persist, leading CEOs in VC-backed firms to have less control over their boards than CEOs in non-VC-backed firms. 


\subsubsection{Politically-Connected Directors}

Firms that deal regularly with government, such as regulated utilities, or ones with significant government contracts, place a high value on being able to influence governmental decisions. Consequently, these firms should have a demand for directors with political connections. Agrawal and Knoeber (2001) test this hypothesis, and, not surprisingly, find that firms that are more reliant on governmental decisions are more likely to appoint directors with backgrounds in law and politics. Extending this idea, Goldman et al. (in press) consider the nature of these connections in greater detail. These authors classify directors by the party to which they belong. Around the time of the 2000 election, which was a very close win for the George W. Bush and the Republican party, firms with Republican-connected boards increased in value while Democratic-connected firms decreased in value. This finding emphasizes the value politically-connected directors can provide and, consequently, the importance of these connections to firms.

\subsubsection{CEOs as Directors}

One of the most common occupations of outside directors is CEO of another firm. CEOs of other firms clearly have management skills and an understanding of the issues facing top management. Fahlenbrach et al. (2008) consider the effect of having CEO directors on boards. These authors find no evidence, however, that CEOs on boards add value, at least relative to other outside directors. This conclusion is somewhat at odds with Fich (2005), discussed in detail later, which finds the announcement that CEOs of well-performing firms will be added to the board generates positive abnormal returns.

Fellow CEOs on the board may, however, reduce firm value in at least one circumstance, namely when a CEO is added to a board as a part of an interlock; that is, when the CEO of one firm is added to the board of a second while the second's CEO simultaneously serves on the board of the first. When directors are added as interlocks, Fahlenbrach et al. find that firm performance declines. This decline is attributed to mutual "back-scratching": The implicit threat of what the first CEO can do for or against the second in the first's role as director causes the second to act more favorably toward the first in the second's role as director. Consistent with this idea, Hallock (1997) finds that interlocked directors receive abnormally high pay. Similar results are found in Kramarz and Thesmar (2006) and Larcker et al. (2005), who use more sophisticated measures of connections between CEOs and boards, and find evidence of worse firm performance and higher CEO pay at firms in which the CEO has connections to the board. Fich and White (2005) explore, more generally, the reasons why CEOs sit on each other's boards. They find that measures of CEO bargaining power-tenure, evidence of ability (Tobin's $Q$ ), and sitting on the nominating committee - are positively correlated with interlocks, while CEO ownership is negatively correlated. These findings are consistent with a view of interlocks as a means of providing the CEO job security. Finally, Bizjak et al. (in press) find that board interlocks increase 
the likelihood of "option backdating," a controversial practice that serves to increase top management's pay by ex post adjusting the date on which options are dated. This finding supports the view that boards play a role in setting corporate policies and provides further evidence that interlocked boards benefit management, possibly at the expense of shareholders.

Overall, there appears to be substantial evidence that interlocks and other outside personal relationships between the CEO and his directors can be associated with poor performance. As before, however, interpreting these results is tricky due to the underlying endogeneity problem. It is difficult to know if the board structure determines the firm's performance or the board structure is merely a manifestation of the power a CEO has over his firm and the problems that stem from that. This distinction is not merely of academic interest; policies to regulate board composition are often proposed and sometimes enacted. The extent to which these policies are likely to be effective depends crucially on the extent to which the board structure causally changes firm performance and is not merely a symptom of underlying issues inside the firm.

Another issue with CEOs as directors is why should the firm the CEO manages permit him to devote time and effort to other firms? Conyon and Read (2006) offer a theoretical explanation. Serving on the boards of other firms helps to build the CEO's human capital. Moreover, the firm can subtract the opportunity cost of his time and effort away from the firm from the compensation it pays him. The interest of the CEO and his firm's owners are not, however, perfectly aligned on this matter insofar as the CEO also gains a personal benefit from service on the boards of other companies (e.g., additional income and prestige). Hence, a firm that did not limit the number of directorships its CEO could accept would find that the CEO accepts more directorships than would be optimal from the shareholders' perspective.

\subsubsection{Stakeholder Representatives on Boards}

Often, especially outside the US, a variety of constituencies (stakeholders) with an interest in a firm are represented on the firm's board. A particularly important set of such stakeholders is labor. Presumably the reason why labor is eager to gain such representation is to influence management to take actions favorable to workers. Faleye et al. (2006) find evidence that supports this notion: Laborcontrolled publicly traded firms tend to invest less in long-term assets, take fewer risks, and exhibit lower labor and total factor productivity. Similarly, Gorton and Schmid (2004) consider employee representation on supervisory boards in Germany. These authors find that when labor has equal representation, firms trade at a $31 \%$ discount to firms with $1 / 3$ employee representation, and have higher payrolls. Both the Faleye et al. and Gorton and Schmid articles suggest that, when labor can affect firm policies, either through board representation or equity ownership, it is able to influence firm policies to benefit workers at the expense of shareholders. 


\subsection{Summary}

While the existence of a board of directors is common to most firms (and other organizations), their structure varies both across firm and over time. The key underlying variable that determines board structure is the power of management relative to the board and outside constituencies. This power manifests itself in a number of observable ways, including the makeup of the board and the rules by which the board can be elected. Two characteristics of boards that are associated in the data with poor performance are staggered boards and interlocked boards. The existence of a staggered or interlocked board is likely a consequence of a powerful CEO who exercises control over his board, and both characteristics are potential ways in which such a powerful CEO can further increase his control over the board.

\section{How Does The Board Work?}

The discussion of boards so far has left the working of the board as a black box. What they do has been discussed, but not how they do it. How do boards function? What are the mechanics by which they do their jobs? These are questions to which we now turn.

An obvious problem in addressing these questions is that what happens inside a boardroom is necessarily private. While some academic research has tried to uncover these workings of the board through interviews and case studies (see Section 2.1 supra), most research has relied on publicly observable data that arguably shed light on the inner workings of the board.

\subsection{The Working of Teams}

A board of directors is a team. There is a lengthy theoretical literature in economics on the workings of teams (see Bolton and Dewatripont, 2005, $\S 8.1$ for an introduction). As, however, was noted earlier, application of this theory to boards does not always lead to clear predictions. For instance, total board effort can increase or decrease with the size of the board.

One might hope to resolve such ambiguous theoretical predictions by turning to the data. If, for example, total board effort is positively correlated with outcomes, then a potential test of size on total effort would be to examine the relation between outcomes and board size. Although, as discussed in Section 2.2, such tests have been run, their interpretation is complicated by jointendogeneity issues. The work that best controls for those issues, Coles et al. (2008), finds ambiguous results: For "simple" firms, Tobin's $Q$ decreases in board size; while, for "complex" firms, it increases in board size. ${ }^{33}$

One interpretation of Coles et al.'s results is as follows. Directors provide the CEO with advice, as suggested by field work (see Section 2.1). Advice is more

\footnotetext{
${ }^{33} \mathrm{~A}$ complex firm is one that scores above the median on an index of complexity, a simple firm is one that scores below. The index is positively related to the number of business segments a firm has, its size, and its leverage.
} 
valuable the more complex the firm. ${ }^{34}$ This is a factor in favor of increasing board size when the firm is "complex."

Without meaning to suggest this isn't the correct interpretation, it does raise questions. Although consistent with field work, one might speculate as to why the CEO relies on the board rather than, say, management consultants for advice? And why is it that the total quality or amount of advice increases with board size (i.e., why is it that the free-riding problem isn't so severe as to make these values decrease with size)?

Alternatively, complex firms could be more difficult to monitor, which could, in theory, warrant more monitors (a larger board). Specifically, let $C(n)$ be the cost of having $n$ directors (e.g., the amount of their compensation plus other associated expenditures). Suppose that, if a problem exists, the independent probability that a given director detects it to be $s p$, where $s$ is a measure of the simplicity of the firm and $p$ is a constant. Without loss of generality, normalize the probability of a problem existing times the benefit of correcting it to one. Then a firm chooses its number of directors, $n$, to maximize

$$
\left(1-(1-s p)^{n}\right)-C(n) .
$$

The cross-partial derivative of (2) with respect to $s$ and $n$ is

$$
(1-s p)^{n-1} p+n(1-s p)^{n-1} \log (1-s p) p,
$$

which has the same sign as

$$
1+n \log (1-s p) .
$$

If $s p>.632$ or for $n$ large enough, (3) is negative - the marginal return to adding directors is decreasing in the simplicity of the firm. Hence, it is optimal for simpler firms to have fewer directors than should more complex firms.

\subsection{Busy Directors}

Firms generally want to have outside directors who are distinguished individuals who also have an ability to add value as directors. Many of these individuals have demanding full-time jobs, such as CEOs, attorneys, or bankers. Even if directors

\footnotetext{
${ }^{34}$ For instance, suppose the quality of advice from director $i$ is $q_{i}$, where $q_{i} \stackrel{\text { iid }}{\sim} F$. The CEO adopts the best advice, which, assume, has a monetary payoff proportional to max $q_{i} / s$, where $s$ is the simplicity of the firm. The benefit from $n$ directors is

$$
\frac{1}{s} \int_{0}^{\infty} q n F^{n-1}(q) f(q) d q \equiv \frac{1}{s} \mathbb{E}\{\max q \mid n\} .
$$

The cross-partial derivative of that expression with respect to $s$ and $n$ is

$$
-\frac{1}{s^{2}} \times \frac{d \mathbb{E}\{\max q \mid n\}}{d n}<0,
$$

where the sign follows because the expectation of the extreme value is increasing in the number of draws. Hence, the marginal benefit of adding directors is declining in the simplicity of the firm.
} 
do not have full-time jobs, some of them are in sufficient demand that they serve on many boards, sometimes as many as ten simultaneously. A concern often voiced about this arrangement is that such "extremely busy" directors will not be able to devote sufficient effort to any one board. The alternative argument is that the directors who are considered "busy" are in fact chosen to be on so many boards precisely because of their high ability, which serves to offset the effect of their lack of time. Not surprisingly, therefore, the effectiveness of such "busy" directors has become an active area of interest.

\subsubsection{Theory}

The simple theory behind the problem of busy directors is that, the busier a director is, the less effort he or she devotes to each of his or her duties. This idea is readily modeled: Suppose, for simplicity, that the benefit a director derives from effort expenditure is the same for all her activities. Hence, her total benefit is $\sum_{m=1}^{M} b\left(a_{m}\right)$, where $a_{m}$ is effort expended on the $m$ th activity, $b: \mathbb{R}_{+} \rightarrow \mathbb{R}_{+}$is the common benefit function, and $M$ is the total number of activities. Critically, assume spending more effort on activity $m$ increases her marginal cost of effort on activity $j$ for any pair of activities $m$ and $j$. This would, for instance, be true if her cost of effort function were $c\left(\sum_{m=1}^{M} a_{m}\right)$, where $c(\cdot)$ is increasing and convex (e.g., her utility for leisure exhibits diminishing marginal utility). If $b(\cdot)$ is concave, then the director optimally allocates her efforts equally across her activities; specifically, effort on activity $m$ satisfies the first-order condition

$$
b^{\prime}\left(a_{m}\right)-c^{\prime}\left(\sum_{j=1}^{M} a_{j}\right)=0 .
$$

We can rewrite (4) as

$$
b^{\prime}\left(a^{*}(M)\right)-c^{\prime}\left(M a^{*}(M)\right)=0,
$$

where $a^{*}(M)$ is the optimal amount of effort she expends on any one activity given that she is undertaking $M$ activities. Using (5), it follows that $a^{*}(M+1)<$ $a^{*}(M)$; that is, if assigned one more activity (board seat), her effort on any given activity falls. ${ }^{35}$

A problem with this simple model is that the number of board seats held by a director is not an exogenous variable (i.e., our director is not compelled to accept $M$ seats). Rather a director has choice. This makes $M$ an endogenous variable, implying that we need to ask why some directors choose to be busier

\footnotetext{
${ }^{35}$ Proof: Suppose not; that is, suppose $a^{*}(M+1) \geq a^{*}(M)$. Because her marginal costs are rising in total effort, it follows that$$
c^{\prime}\left(M a^{*}(M)\right)<c^{\prime}\left((M+1) a^{*}(M+1)\right) .
$$

Expression (5) then entails$$
b^{\prime}\left(a^{*}(M)\right)<b^{\prime}\left(a^{*}(M+1)\right) ;
$$

but, because she has diminishing marginal benefits, this last expression implies the contradiction $a^{*}(M)>a^{*}(M+1)$.
} 
than others? This, in turn, can alter our conclusion that busier directors devote less effort on a given board than their less-busy colleagues. To see this, assume there are types of directors, where a director of type $\theta$ derives benefit $\theta b\left(a_{m}\right)$ from effort expended on her $m$ th activity. A type- $\theta$ director's utility, as a function of $M$, is

$$
M \theta b\left(a^{*}(M)\right)-c\left(M a^{*}(M)\right) .
$$

Utilizing the envelope theorem, the cross-partial derivative of (6) with respect to $M$ and $\theta$ is readily shown to be $b\left(a^{*}(M)\right)>0$; that is, higher-type directors enjoy a greater marginal benefit from adding an activity than do lower-type directors. Consequently, higher-type directors will optimally choose to do more activities than lower-type directors. Moreover, because a higher-type director enjoys a higher marginal return to effort than does a lower-type director, a higher-type director expends more effort than a lower-type director holding constant the number of activities. In other words, busier directors are higher types who would, thus, expend more effort per activity were they restricted to the same number of activities as less-busy (lower-type) directors. This is a countervailing effect vis-à-vis the less-effort-the-more-activities effect identified in the previous paragraph. Which of the two effects dominates is, a priori, indeterminate. Theory, therefore, does not offer a definitive prediction about the effort of busy directors once one recognizes that the number of board seats held is endogenous.

To illustrate why this is an important fact to recognize, suppose that $b(a)=$ $\log (a)$ and $c(x)=x^{2} / 2$. Straightforward calculations reveal that $a^{*}=\sqrt{\theta / M}$. Expression (6) is readily shown to equal

$$
\theta M \log \left(\sqrt{\frac{\theta}{M}}\right)-\frac{\theta}{2 M}
$$

which is a globally concave function of $M$ for any $\theta$. Suppose there are just two types, 9 and 15. Table 1 demonstrates that the optimal number of activities (directorships) is 4 for the 9-type and 6 for the 15-type director. Because $\sqrt{15 / 6}>\sqrt{9 / 4}$, it follows that the directors who are busier in equilibrium (the 15-type) expend more effort on each of their directorships than do the less-busy directors (the 9-type) on each of theirs. In other words, busier does not equate to less effort in this example.

\subsubsection{Empirical Work on Busy Directors}

Given that theory is ambiguous in its prediction of the overall effect of busy directors on firms, people have attempted to discern empirically which of the two effects dominates. In other words, is the fact that busy directors are likely to be relatively high quality directors more important than the possibly impact of their potential lack of time on their effectiveness? Consistent with the quality arguments, Kaplan and Reishus (1990), Booth and Deli (1996), and Ferris et al. (2003) find that there is a positive relationship between a firm's performance 
Table 1: Utility for different director types according to number of directorships taken. Numbers are calculated according to the example connected to expression (7) in the text.

\begin{tabular}{|c|r|r|}
\hline \multirow{2}{*}{ Directorships } & \multicolumn{2}{|c|}{ Utility for Type } \\
\cline { 2 - 3 } & $\theta=9$ & $\theta=15$ \\
\hline 3 & 13.33 & 33.71 \\
\hline 4 & $\mathbf{1 3 . 4 7}$ & 37.78 \\
\hline 5 & 12.33 & 39.70 \\
\hline 6 & 10.20 & $\mathbf{3 9 . 9 8}$ \\
\hline 7 & 7.27 & 38.94 \\
\hline
\end{tabular}

and the additional directorships acquired by its board members: when the firm cuts its dividend its directors lose directorships (Kaplan and Reishus); when a firm performs well, its directors are more likely to land seats on other boards (Ferris et al.). Ferris et al. also find that "busy" directors are equally likely to serve on committees as other directors and are no more likely to be sued than other directors, which these authors interpret as supporting the view that busy directors do not shirk on their responsibilities.

However, not being sued and agreeing to serve on committees seem like relatively indirect tests of the hypothesis that being busy hurts performance. Fich and Shivdasani (2006) provide more direct tests of this hypothesis. Fich and Shivdasani find that firms with a majority of directors who serve on three or more boards have lower market-to-book ratios than other firms; moreover, they have a lower sensitivity of CEO turnover to performance. In addition, stock prices increase when busy directors depart the board, and when already busy directors add an additional board seat, the stock price of the firms on whose boards they serve declines. Overall, these findings suggest having busy directors on a board can fail to be in the firm's interests.

\subsection{Board Committees}

Boards usually do most their work in committees, and data on the committee structure is generally publicly available. Some authors have used these data to draw inferences about the functioning of the board.

Shivdasani and Yermack (1999) use information about the nominating committee to draw inferences over the CEO's influence on the board. These authors find that, when the CEO serves on the nominating committee or when there is no such committee, fewer independent directors are appointed and the stock price reaction to independent director appointments is lower than when there is a nominating committee that does not include the CEO. This effect could be causal, in that being on the nominating committee could allow CEOs to exercise control over board selection, or it could simply reflect that more powerful CEOS are both able to get appointed to nominating committees and also to influence 
director selection. In either case, the Shivdasani and Yermack findings are consistent with the view that powerful CEOs are able to influence the structure of their board

Klein (1998) considers the relation between firm performance and board committee structures. She finds that, although there is no relation between overall board composition and firm performance, the number of insiders on the finance and investment committees is positively associated with better performance. The same causality question as discussed above is relevant for interpreting her findings: Do insiders on the finance and investment committees cause good performance or is this committee structure somehow a consequence of better performance? In particular, if firms can improve performance substantially simply by rearranging their committee structure, why haven't all firms "optimally" rearranged their committees? On the other hand, it is possible that firms face external pressure to staff committees with outsiders, which leads them to suboptimize by having too few insiders on key committees.

More recently, Adams (2003) and Hayes et al. (2004) have considered board committee structure in more detail. Adams uses the committee structure of boards as a way to infer the nature of the tasks to which boards spend their time. She finds that boards of diversified firms devote more time to monitoring while boards of growing firms devote more time to strategic issues. Hayes et al. find a number of results, most of which reflect the number of committees and their tasks. The committees of larger firms and ones that pay dividends tend to have more tasks assigned to them, while those in firms with higher CEO ownership have fewer tasks. These findings suggest that the board is part of the professionalization of the firm. As the firm becomes larger, more mature, and transitions from founder management toward professional management, the board plays a larger role in corporate governance.

Finally, a number of papers have used data on audit committee membership to draw inferences about the accounting process inside of firms. ${ }^{36}$ This literature looks at the quality of accounting, such as whether firms manipulate earnings through accruals and whether a firms earnings response coefficient means that earnings are informative about value. In general, these papers find that the makeup of the audit committee is correlated with these variables of accounting quality. Once again, it is difficult to infer causality from these studies. While it is possible that audit committees play a role in improving accounting practice, it is also possible that firms determined to improve their accounting change both their accounting practices and their audit committee membership.

\section{$5 \quad$ What Motivates Directors?}

Directors are agents of the shareholders. Because their inherent motives are unlikely to be aligned with the shareholders' interests, at least in all situations, it is worth considering this misalignment, its consequences, and its remedies.

\footnotetext{
${ }^{36} \mathrm{~A}$ partial list of this literature includes K. Anderson et al. (2003), R. Anderson et al. (2004), Deli and Gillan (2000), Klein (2002), and Xie et al. (2003).
} 
Given that the preceding discussion touches on these issues here and there and we seek to avoid unnecessary repetition, this section will prove to be relatively short.

\subsection{Direct Compensation}

Like all economic actors, directors may be presumed to prefer greater wealth to less wealth; hence, they should be responsive to financial incentives. Indeed, firms routinely use a variety of such incentives including additional fees for attending meetings, stock and option grants, and performance bonuses. For a sample of 1198 firms in 2002, Bryan and Klein (2004) report that the average director received $\$ 102,976$ in total annual compensation; of this, $\$ 71,839$ was incentive pay and $\$ 31,137$ was cash. The latter figure also contains an incentive component insofar as approximately $\$ 8129$ are attendance-contingent fees. Roughly $73 \%$ of firms in the sample made option grants and $37 \%$ stock grants. ${ }^{37}$ Yermack (2004) finds evidence that when all incentives are accounted for (including keeping current board seats and gaining new ones), the average outside director of a Fortune 500 firm gains 11 cents for each $\$ 1000$ increase in firm value. He finds that a one standard deviation change in the market capitalization of the median sample firm (a $\$ 2.6$ billion change) results in a $\$ 285,000$ change in an outside director's wealth.

\subsubsection{Theory}

From a theoretical perspective, the basic ideas of incentive pay are well known and have been analyzed at depth (see, e.g., Holmstrom, 1979, Shavell, 1979, and Grossman and Hart, 1983; Bolton and Dewatripont, 2005, offers a textbook treatment). The three-level hierarchy of shareholders-directors-management generates some additional issues, such as possible collusion between directors and management, but many of these have also been addressed in the broader literature (see, e.g., Tirole, 1986, 1992).

An interesting board-specific theoretical analysis is Kumar and Sivaramakrishnan (2008). First, unlike almost all the theoretical literature on boards, Kumar and Sivaramakrishnan examine the role of the board in setting the CEO's incentive compensation. Second, the authors explicitly study the role of incentive pay for directors with respect to the performance of their duties. Among their findings are that board independence and board incentive pay could be substitutes; independent boards could be less diligent monitors than less-independent boards; and, as a consequence, having a maximally independent board need not be best for the shareholders ceteris paribus. The basic intuition is as follows. A less-independent board, knowing it will not be as strong a negotiator against the CEO when it comes time to set his compensation, has a stronger incentive than does a more-independent board to learn payoff-relevant information prior to those negotiations. The reason being that such information helps to offset

\footnotetext{
${ }^{37}$ See Brown (2007) for a survey of some of the, largely legal, issues connected to director compensation.
} 
their weaker bargaining position. In essence, a less-independent board is playing a "lash itself to the mast" strategy because it knows it won't be able to resist the CEO's demands as well as it would otherwise like. Because a lessindependent board has a stronger incentive to gather information, the strength of the compensation incentives it requires is less than would be required by a more independent board. Hence, it is cheaper for the shareholders to employ a less dependent board in terms of inducing the board to learn payoff-relevant information. Of course, the fact that it is a more dependent board means the shareholders bear other costs; but as Kumar and Sivaramakrishnan show, it is possible for the former effect to be great enough to outweigh these other costs.

Kumar and Sivaramakrishnan's model is quite rich and, thus, complex. Fortunately, a much simplified version of it can be used to illustrate the article's most important insights. A firm can have one of two possible projects. One project requires an investment of $I_{\ell}$ and pays off $V$, the other requires an investment of $I_{h}$ and also pays off $V$. Assume $V>I_{h}>I_{\ell}$. Let the commonly known probability that the project is the $\ell$-type be $p$. Before approaching the board for the investment funds, $I$, the CEO learns the project type; this is his private information. However, by expending $c>0$, the board can also learn the project type. Whether or not it has done so is known by the CEO, but not by the shareholders. The CEO's preferences are $u(w)+I$, where $w$ is his compensation and $u(\cdot)$ his utility for money. Note the CEO prefers to run a larger project, in terms of investment funds, than a smaller project. This is a fairly standard assumption in the literature, reflecting either a preference for empire building and grandiose projects, or that having greater funds available provides the CEO more perks. Consequently, regardless of its true type, the CEO would like to claim the project is the $h$ type. Because the CEO's marginal utility from each dollar invested is 1 , it is clear that there is no incentive contract that can be employed (short of selling him the enterprise) that would induce him to announce the project type accurately. Because of the asymmetry of information with respect to the value of the firm, selling it to the CEO would not be in the shareholders' interests. Hence, there is no incentive contract for the CEO; we can think of his utility as just being $I$. There are two kinds of boards that can be employed, independent and dependent. The utility of an independent board is $\alpha(V-I)$, where $\alpha$ is the proportion of the firm granted the directors as an incentive. The utility of a dependent board is $\alpha(V-I)+\delta I$, where $\delta>0$ is a parameter that reflects the board's dependence on the CEO, specifically the degree to which it worries about the CEO's utility. The timing of the model is that the shareholders determine which kind of board to employ and what its compensation will be. Next the CEO learns the project type and the board, if it elects to expend $c$, also learns the type. The CEO then seeks approval from the board to invest. Finally, payoffs are realized.

To begin to solve the model, consider a situation in which the board is ignorant. The board has a choice, it can fund all projects, which means it will always be asked to invest $I_{h}$ by the CEO, or it can restrict itself to only allowing the CEO to invest $I_{\ell}$ (assume if the project is $h$, there is no value to the CEO of proceeding with insufficient funding; that is, he just shuts the firm down). 
Observe from the shareholders' perspective or the perspective of an independent board, the board should pursue the latter course of action if

$$
p\left(V-I_{\ell}\right)>V-I_{h} .
$$

Observe that this is a sub-optimal rule because, recall, $V>I_{h}$. The shareholders/independent board forgo some profitable investment to avoid paying the CEO an information rent. Hence if (8) holds - as we will henceforth assume to be the case - there is potential room for improvement. A dependent board will fund all projects if

$$
\alpha\left(V-I_{h}\right)+\delta I_{h}>p \alpha\left(V-I_{\ell}\right)+p \delta I_{\ell} .
$$

Observe it is possible that both (8) and (9) hold, in which case the shareholders are worse off with an ignorant dependent board than they would be with an ignorant independent board.

The board does not have to remain ignorant; that is, it can choose to expend $c$ and learn the project's type. If it does so, then it will fund all projects, but can restrict the CEO to $I_{\ell}$ if the project is the $\ell$ type. The expected payoff if the board will learn the project type is

$$
V-p I_{\ell}-(1-p) I_{h} .
$$

Observe that (10) is the highest expected value the firm can have. Obviously, expending $c$ would be a waste if the dependent board was so weak that it would approve funding of $I_{h}$ even if it knew the project was the $\ell$ type. To avoid that, we require

$$
\alpha\left(V-I_{\ell}\right)+\delta I_{\ell} \geq \alpha\left(V-I_{h}\right)+\delta I_{h}
$$

Expression (11) holds whenever $\alpha \geq \delta$. Note that the parameters can be such that (8), (9), and (11) all hold.

The expected gain for an independent board from learning the project type is

$$
\alpha(1-p)\left(V-I_{h}\right) .
$$

Hence, the minimum value of $\alpha$ such that an independent board will wish to learn the project type is

$$
\alpha_{\text {ind }}=\frac{c}{(1-p)\left(V-I_{h}\right)} .
$$

The expected gain for a dependent board from learning the project type is

$$
\left(\alpha V-(\alpha-\delta)\left(p I_{\ell}+(1-p) I_{h}\right)\right)-\left(\alpha V-(\alpha-\delta) I_{h}\right) .
$$

Hence, the minimum value of $\alpha$ such that a dependent board will wish to learn the project type is

$$
\alpha_{\text {dep }}=\delta+\frac{c}{p\left(I_{h}-I_{\ell}\right)} .
$$


Observe that if the probability of the $h$-type project or its return (or both) are relatively small, while the probability of the $\ell$-type project or the cost savings it represents (or both) are relatively large, then it is less costly for the shareholders to induce a dependent board to learn the project's type than it is for them to induce an independent board to learn the project's type (i.e., $\alpha_{\text {dep }}<\alpha_{\text {ind }}$ in such situations). In essence, because a dependent board knows it will lose more in the future if ignorant, the value of information is intrinsically greater for it. Because it can be cheaper to induce a dependent board to learn the project's type, shareholders can rationally prefer a dependent board to an independent board. For example, suppose:

$$
V=10, \quad I_{\ell}=0, \quad I_{h}=\frac{77}{8}, p=\frac{1}{16}, \quad \text { and } c=\delta=\frac{1}{8} .
$$

Then

$$
\alpha_{\mathrm{dep}}=\frac{205}{616} \text { and } \alpha_{\mathrm{ind}}=\frac{16}{45} .
$$

Because the former is less than $1 / 3$ and the latter greater than $1 / 3$, it follows that $\alpha_{\text {dep }}<\alpha_{\text {ind }}$. The only thing left to check is that the shareholders wouldn't wish to set $\alpha=0$ (assume ignorant independent directors still restrict the firm to the $\ell$-type project even when $\alpha=0$ ). Expected return to shareholders if $\alpha=0$ is $5 / 8$ if the directors are independent and $3 / 8$ if the directors are dependent. The shareholders' payoff if they incentivize dependent directors is

$$
\frac{411}{616} \times\left(\frac{1}{16} 10+\frac{15}{16} \frac{3}{8}\right)=\frac{51,375}{78,848}>\frac{50,000}{80,000}=\frac{5}{8} .
$$

Hence, for the parameter values above, the shareholders do best to hire and incentivize dependent directors. Note, though, for other parameter values, the shareholder do best to hire independent directors. For example, if we change $p=1 / 8$ and $I_{h}=9$, then

$$
\alpha_{\mathrm{dep}}=\frac{17}{72} \text { and } \alpha_{\text {ind }}=\frac{1}{7} ;
$$

hence, an independent board would be best.

\subsubsection{Empirical Work}

There has been some empirical work on the determinants of director compensation. Vafeas (1999) conducts a matched-sample analysis with a sample of 122 firms that adopted a director compensation scheme (a plan providing for the grant of stock or options) between 1989 and 1995 and 122 that did not (and had not). He finds that a strongly significant predictor of adoption is the proportion of outside directors, which is positively related to adoption. Comparing adopters and their matched non-adopters three years after plan adoption, Vafeas finds adopters continue to have a higher proportion of outside directors. A comparison of differences between adopters and non-adopters, along 
with suggestive, but not always statistically significant, regression coefficients, indicate that firms that adopt tend to be larger (as measured by sales), are less likely to have an unaffiliated blockholder, and have busier directors. Vafeas puts forth the interpretation that adopting firms are more reliant on the board as a monitoring device and, thus, contingent compensation is part of this governance strategy.

Consistent with Vafeas, Bryan and Klein (2004) find evidence that firms with greater agency problems make greater use of option compensation for outside directors. ${ }^{38}$ In contrast to Vafeas, they find no evidence that the percentage of outside directors is a significant predictor of option compensation.

Like Bryan and Klein, Fich and Shivdasani (2005) find that firms with high market-to-book ratios are more likely to utilize option compensation for their directors than firms with low market-to-book ratios. They further find that, consistent with an attenuation-of-agency-problems story, the stock market reacts favorably to the adoption of a director stock-option plan. Adoption led to significant cumulative abnormal returns $(0.31 \%$ for all adopters, $0.18 \%$ for a subsample of "uncontaminated" events). Adoption also led to an improvement in the earnings-per-share forecast.

On the other hand, it is possible that, instead of being a solution to an agency problem, director compensation plans are evidence of an unresolved agency problem. Brick et al. (2006) find a strong positive correlation between excess CEO compensation and excess director compensation, where excess compensation is defined as the residual from a pay-for-performance regression. If the regression residuals were truly random errors, then they should be uncorrelated. Correlation indicates systematic factors within each firm. Brick et al. suggest that one such systematic factor could be "cronyism" between the directors and the CEO; that is, the directors and CEO collude together against the shareholders to improperly increase their compensation.

Other authors (Perry, 1999; and Adams and Ferreira, 2008a) have sought to determine whether incentive pay for directors has an effect on their actions. Adams and Ferreira (2008a) estimate the effect of meeting-attendance fees on directors' decisions to attend board meetings. These authors find, somewhat surprisingly given the high opportunity cost of most directors' time, that receiving as little as $\$ 1000$ per meeting significantly increases attendance. Consistent with the view that incentive pay improves performance, Perry finds that incentive pay makes outsider-dominated boards even more likely to dismiss the CEO for poor financial performance.

\footnotetext{
${ }^{38}$ The authors use measures of investment opportunities (either R\&D expenses or market-tobook ratio) as an agency variable; the idea being that having more potentially squanderable investment opportunities means the agency problem is worse. Other agency variables are leverage and being regulated; the disciplining nature of debt or outside regulation reduces agency problems. More controversial is a measure of closeness to financial distress; the authors argue that distress leads to greater creditor control, which reduces the agency problem. Alternatively, the higher likelihood that the stock will be worthless reduces the value of stock options, making them a less-powerful incentive for directors. Or, as another alternative, the creditors, worried about the asset-substitution problem, want to avoid giving directors incentives to gamble.
} 
An important consideration when evaluating studies of director compensation is that both directors' compensation and their actions could be a function of some third factor. For example, one possible source of variation in governance is between professionally managed and family firms. It is likely that professionally managed firms are more likely to hire compensation consultants when designing director compensation systems, and consequently are more likely to include incentive-based plans, and are also likely to have higher levels of compensation (given directors must be hired via arms-length transactions). Such an explanation is often difficult to rule out - although Adams and Ferreira (2008a) are largely able to do so by using both director fixed effects and directorship effects (which control for family versus non-family firms) and instrumental variables to address endogeneity problems. It is also likely that these professionally managed firms have higher market-to-book ratios, higher attendance at board meetings, and more performance-based evaluation of the CEO. The professionalism of the management team is only one of many possible omitted variables. On the other hand, there is no "smoking gun" to indicate that one or more omitted factors are the explanation for the results of these studies (and, as noted, Adams and Ferreira, 2008a is very careful). Nevertheless, as we have emphasized, omitted variables are always a worrisome possibility when interpreting these (and other) findings.

\subsection{Reputational Concerns}

What other motivations, besides direct compensation, could affect director behavior? A possible motive that has been heavily investigated is the concern that directors have for being seen as able business people. An idea, dating back at least to Fama (1980), is that concern for his reputation will cause an agent to act more in his principal's interests than standard approaches to agency might suggest. On the other hand, as Holmstrom (1999) observes, reputational concerns are not sufficient to eliminate agency problems and they can, in fact, create additional ones. With respect to the latter, reputational concerns can generate agency problems with respect to the agent's choice of risky projects. ${ }^{39}$

Directors' reputations would seem particularly important in the market for directorships. A strong reputation presumably aids in getting more board seats or retaining the ones already held, a weak reputation the opposite. Gilson (1990) and Kaplan and Reishus (1990) examine this possibility empirically. They find that poorly performing CEOs are less likely to gain board seats on other companies than well-performing CEOs (with poor performance being indicated by financial distress or a reduction in dividends, respectively, in the two studies).

\footnotetext{
${ }^{39}$ In Holmstrom (1999), reputational concerns cause the agent to shy away from risky projects. As, however, others have noted, that conclusion depends on whether outside observers know the risk of the project taken. If they do, then an agent could rationally be overly risk loving when choosing projects. The reason is that observers will not update their beliefs about the agent's abilities much in response to a risky project's outcome, because it is a noisy signal; consequently, the risk to the agent's reputation is lower than if he undertook a less risky and, hence, more informative project. See, e.g., Hermalin and Weisbach (2008) for a more complete discussion of this issue in a governance context.
} 
Fich (2005) looks at the stock-price reaction to adding directors of different qualities. Most noticeably, he finds that the cumulative abnormal return in response to the addition of a director who is CEO of another firm is significantly greater the higher the industry-adjusted ROA of his firm is. The new director's holding an MBA also has a positive impact on the cumulative abnormal return, albeit at a marginal level of significance. As a possibly sobering finding about our reputations, adding academics to a board is associated with a negative return, although the effect is not statistically significant.

Fich and Shivdasani (2007) examine the effect on directors' reputations if they sit on the boards of firms that are the subject of shareholder class-action lawsuits alleging financial fraud. They find that outside directors are no more likely to leave the board of the sued firm than they would be otherwise. These directors do, however, see a significant drop in other board seats held. The size of this drop is greater the more severe the fraud allegations (there is an associated formal action by the SEC) and when they arguably bear greater responsibility for monitoring fraud (they serve on the audit committee). Finally, these "tainted" directors are more likely to lose directorships at firms with arguably stronger corporate governance (as measured by the Gompers et al., 2003, index) and their departure is associated with positive cumulative abnormal returns for these firms.

Although such studies are valuable, it is worth observing that they touch only on measures of reputation visible to the econometrician; they don't necessarily pick up on "soft" dimensions of reputation. In particular, a director who wishes to maintain or obtain board seats could, at least in theory, face a reputational tradeoff. As the studies above indicate, a director who develops a public reputation as a poor monitor is hurt with respect to the number of board seats he or she holds. At the same time, however, a director who develops a private reputation as a poor monitor - that is, as someone unlikely to rock the boat - might be favored by CEOs who are looking to acquire power at the expense of the board. Certainly, a number of the models discussion in Section 2.2 rely on there being observable (to the CEO at least) differences across directors in the intensity with which they carry out their monitoring roles.

A model that partially gets at this dual tension is Warther (1998). In his model, there is a three-person board consisting of two outside directors and the CEO. The outside directors care about their public reputation, so wish to remove a poorly performing CEO. The CEO, of course, never votes for his own removal, so any removal requires unanimity between the outside directors. A problem in achieving unanimity is that the two outside directors receive private signals of the CEO's ability that are, conditional on his ability, independently distributed. The outside directors can share information, but only in a costly manner: an outside director who indicates she has a negative signal of the CEO's ability will be punished for her disloyalty to the CEO by losing her board seat if she fails to oust him. Consequently, both directors can receive moderately bad signals about the CEO, such that it would be optimal to oust him, but neither speaks up for fear of losing her seat. If, however, a director's signal is bad enough, then (i) her concern for her public reputation will be more severe and (ii) the more 
likely it is that her co-outside director has also received a bad signal; hence, in this case, she speaks out against the CEO. The overall result is that only truly awful CEOs get fired, with too high a proportion of weak CEOs' getting to keep their jobs.

As formulated, there are two points of concern with the Warther model. First, why has the CEO been granted the power to determine who remains on the board? If the CEO can't retaliate against a boat-rocker, the problem disappears. Second, why don't the outside directors share their evidence privately from the CEO and coördinate their subsequent actions? In the Warther model, the directors, having shared information, will agree as to the CEO's ability and will, thus, agree about whether he should go or stay; hence, the CEO's power to rid himself of a trouble-making director is no longer relevant. As noted previously, granting the CEO an ability to influence board membership is consistent with field studies (e.g., Mace, 1971), but this doesn't explain why he has that power. It is possible that integrating Warther's model into a bargaining-type model of board determination (e.g., Hermalin and Weisbach, 1998) could rationalize the CEO's ability to retaliate against dissenting directors. The second issue might also be finessed by a suitable change in the model. Suppose the directors, for some reason, do not agree what the standard for dismissal should be. The more hard-nosed director could be reluctant to approach the more lenient director for fear (i) they would reach different conclusions and (ii) the more lenient director might rat her out to the CEO (perhaps to curry favor with the CEO, to avoid future problems with a dissident director, or to promote a private reputation among CEOs as a director who doesn't rock the boat).

\section{Conclusions}

Corporate governance, and in particular the role of boards of directors, has been the topic of much attention lately. Although this attention is particularly topical due to well-publicized governance failures and subsequent regulatory changes, corporate governance is an area of longstanding interest in economics (dating back to at least Adam Smith, 1776).$^{40}$ Because of corporations' enormous share of economic activity in modern economies, the extent to which corporations deviate from value-maximization is extremely important. Consequently, corporate governance and the role of boards of directors is an issue of fundamental importance in economics. Understanding the role of boards is vital both for our understanding of corporate behavior and with respect to setting policy to regulate corporate activities.

Given the fundamental importance of the issue and its prominent place in the public eye, it is not surprising that there has been a surge of research on

\footnotetext{
${ }^{40}$ With respect to directors, Smith wrote "The directors of such companies, however, being the managers rather of other people's money than of their own, it cannot well be expected that they should watch over it with ... anxious vigilance ... Negligence and profusion, therefore, must always prevail, more or less, in the management of the affairs of such compan[ies]" (Book V, Part III, Article I, "Of the Publick Works and Institutions which are necessary for facilitating particular Branches of Commerce," paragraph 18).
} 
boards of directors; indeed, perhaps the surprising fact is that it has taken so long for boards to become such an active topic of research. We survey this literature here, paying special attention to that done by the economics and finance professions, and also to that research done subsequent to the Hermalin and Weisbach (2003) survey. We apologize in advance to authors whose work we have neglected; one of the difficult aspects of writing this survey is that there are new papers appearing nearly every day, outstripping our capacity to write about them! $!^{41}$

Boards of directors are difficult institutions to study. The two questions most asked about boards concern what determines their makeup, and what determines their actions. These questions are, however, fundamentally intertwinedthe makeup of boards is interesting because it affects what the board does; and, consequently, their makeup is influenced by a desire to affect what they do. This problem of joint endogeneity is vexing for both theoretical and empirical research on boards; research that focuses on one side of the equation while ignoring the other is necessarily incomplete and the results misleading. Nevertheless, progress has been made, much of it since the Hermalin and Weisbach (2003) survey (no causal link is implied).

Empirical study of boards is difficult for a number of reasons. First, one must deal with broader than ideal classifications of directors. An outside director, for instance, gets coded as such whether she is truly independent or she's the CEO's oldest friend. ${ }^{42}$ Second, nearly all variables of interest are, as discussed, jointly endogenous. Unlike the situation in some other areas of economics, there are no cure-all instruments that one can use to deal with this endogeneity. Ultimately, much of what one learns about boards is about equilibrium associations. Causality, in the usual sense, is often impossible to determine. For example, consider Weisbach's (1988) findings that outside directors appear more responsive to performance in the CEO retention decision than inside directors. Because the directors in question were determined through some equilibrium (albeit, possibly, second-best) selection process, one does not have a classic experiment in which different director types are randomly assigned to control and treatment pools. Whether random allocations of directors would yield similar findings is unknowable and, thus, one cannot be sure that the findings, although both sensible and suggestive, are not driven by some unseen third force that determines the proportion of outsiders on the board, the performance of the CEO, and proclivities of the former to fire the latter.

Ultimately, many of the strongest empirical regularities that have been found can best be interpreted as statements about both the director-selection process and their direct effect on board actions. For example, staggered boards tend

\footnotetext{
${ }^{41} \mathrm{~A}$ possible reason for the growth in the literature is better data availability. A number of new databases on boards have become available and have been used in a number of studies. A database provided by Compact Disclosure has a long time series, running from 1988 to the present, while an alternative database provided by IRRC has detailed information on committee structure and the professional background of directors. Both databases are used and described in Fahlenbrach (in press).

${ }^{42}$ Hwang and Kim (in press) and Cohen et al. (2008) are two recent attempts to estimate which outside directors are truly independent.
} 
to base CEO-retention decisions less on their CEO's performance than do nonstaggered boards. Why? Because, perhaps as the consequence of past good performance, the CEO gains bargaining power, which he uses to protect himself. Thus, for instance, he arranges for his board to become staggered; but increasing his power in this way comes at the cost of a reduced ability to discipline him in the future should circumstances warrant. Hence, in the longer run, firms with staggered boards will have lower valuations than do firms with non-staggered boards. A similar story can be told for any decrease in board power, such as the creation of interlocked boards.

Other empirical results can be interpreted sensibly by considering both the selection and actions of boards. For example, there are a number of studies that look at the actions of outside directors that tend to find that boards dominated by outsiders tend to be more shareholder-friendly than boards dominated by insiders. ${ }^{43}$ Yet, studies that have examined the overall performance of firms with different kinds of boards have all found little or no difference in overall performance. ${ }^{44}$ These ostensibly conflicting results make sense when both the selection and action issues are considered. Outside directors are probably better from a shareholder perspective, but because they tend to be added following poor performance (see, e.g., Hermalin and Weisbach, 1988) or most demonstrate their value in crisis situations, the relation between outsider directors and firm value is obscured.

Theory, too, faces its hurdles. Boards are only part of the corporate governance equation, but an all-inclusive model is impractical given the complexities of governance. Even limiting attention to boards, it is hard to decide which institutions should be treated as exogenous and which as endogenous. Letting too much be endogenous and the models become unwieldy and often fail to yield definitive results. Treating too much as exogenous and critical points of joint endogeneity get overlooked, rendering conclusions that are suspect.

Despite these issues, progress has been made. Models linking the determinants of the board and its monitoring function have proved reasonably robust and broadly consistent with subsequent empirical analyses. There has also been progress on models that examine the board's role in setting strategy, although their conclusions are difficult to test empirically and these models have not always been as sensitive to joint-endogeneity issues as would be ideal.

Where do we see research on boards headed? The open questions are many and often fundamental. For instance, are the various means of governing a corporation complements or substitutes? That is, do firms tend to be stronggovernance firms across all the various dimensions of incentive compensation, openness to takeovers, and board independence? Or does strength in one area correspond to weakness in another? At a theoretical level, this question is almost surely impossible to answer, but one can hope to see progress on the empirical side. Even understanding whether governance mechanisms are complements or substitutes, one is left to ponder the sources of heterogeneity in governance that

\footnotetext{
${ }^{43}$ See, for example, Weisbach (1988), Shivdasani (1993), and Brickley et al. (1994).

${ }^{44}$ See, for example, MacAvoy et al. (1983), Hermalin and Weisbach (1991), or Bhagat and Black (1999).
} 
we observe; how is such heterogeneity best explained? Although there has been some work in this area (consider, e.g., Hermalin, 1994, as an early attempt), there are still many open questions. Other promising areas for theory are how the board fits into the CEO succession process; the role of the complexity of a firm's operations and environment on the choice of directors and their actions (we sketched possible paths to explore above); more dynamic models of board evolution and the long-term path of governance; modeling board interactions (Warther, 1998, representing one line of approach); and what benefit, other than protecting the CEO, insiders on a board might play.

Empirical work will need to continue to devise ways of dealing with the joint-endogeneity issue. A possible strategy in this regard is to look for "natural experiments." One set of such experiments are changes in regulation. In particular, if a new regulation is put in place, it is possible that some firms are already in compliance with it, while others are not. If bargaining models of governance (e.g., Hermalin and Weisbach, 1998) are correct, then we should see little to no change in CEO compensation for those firms that were already in compliance, while CEO compensation should rise sharply for those firms that must come into compliance. If firms set their governance structure optimally given their constraints, then the long-run performance of those firms for which the new regulations bind should be worse than that of those already in compliance. In the short run, however, the results could be more confused, to the extent that the regulation holds up the CEO for the shareholders' benefit; that is, to the extent that the CEO bargained for something that benefitted him at shareholder expense, but had that bargain subsequently undone by the regulation, there would be short-term gain by shareholders (this is why it may be more relevant to consider CEO compensation than firm value). 


\section{References}

Adams, Renée B., "What do Boards do? Evidence from Board Committee and Director Compensation Data," 2003. Working Paper, University of Queensland.

- and Daniel Ferreira, "A Theory of Friendly Boards," Journal of Finance, January 2007, 62 (1), 217-250.

_ and _ , "Do Directors Perform for Pay?," Journal of Accounting and Economics, 2008, 46 (1), 154-171.

_ and _, "Women in the Boardroom and Their Impact on Governance and Performance," 2008. Working paper, University of Queensland.

_ , Heitor Almeida, and Daniel Ferreira, "Powerful CEOs and their Impact on Corporate Performance," Review of Financial Studies, 2005, 18, 14031432 .

Agrawal, Anup and Charles R. Knoeber, "Do Some Outside Directors Play a Political Role?," Journal of Law and Economics, 2001, 44, 179-198.

Almazan, Andres and Javier Suarez, "Entrenchment and Severance Pay in Optimal Governance Structures," Journal of Finance, April 2003, 58 (2), $519-547$.

Anderson, Kirsten, Daniel N. Deli, and Stuart L. Gillan, "Boards of Directors, Audit Committees, and the Information Content of Earnings," 2003. Working Paper, Arizona State University.

Anderson, Ronald C., Sattar A. Mansi, and David M. Reeb, "Board Characteristics, Accounting Report Integrity, and the Cost of Debt," Journal of Accounting and Economics, September 2004, 37, 315-342.

Baker, Malcolm and Paul A. Gompers, "The Determinants of Board Structure at the Initial Public Offering," Journal of Law and Economics, October 2003, $46(2), 569-597$.

Baranchuk, Nina and Philip H. Dybvig, "Consensus in Diverse Corporate Boards," Review of Financial Studies, in press.

Baysinger, Barry D. and Henry N. Butler, "Corporate Governance and the Board of Directors: Performance Effects of Changes in Board Composition," Journal of Law, Economics, and Organization, Spring 1985, 1 (1), $101-124$.

Bebchuk, Lucian Arye and Alma Cohen, "The Costs of Staggered Boards," Journal of Financial Economics, 2005, 78, 409-433.

- and Jesse M. Fried, Pay without Performance, Cambridge, MA: Harvard University Press, 2004. 
-, John C. Coates, and Guhan Subramanian, "The Powerful Antitakeover Force of Staggered Boards, Theory, Evidence, and Policy," Stanford Law Review, 2002, 54, 887-952.

Becht, Marco, Patrick Bolton, and Ailsa Röell, "Corporate Governance and Control," in George Constantinides, Milton Harris, and René Stulz, eds., The Handbook of the Economics of Finance, Amsterdam: North-Holland, 2003.

Bhagat, Sanjai and Bernard Black, "Is There a Relationship Between Board Composition and Firm Performance?," Business Lawyer, 1999, 54, 921-963.

- and Richard H. Jefferis, The Econometrics of Corporate Governance Studies, Cambridge, MA: MIT Press, 2002.

Bizjak, John, Michael Lemmon, and Ryan Whitby, "Option Backdating and Board Interlocks," Review of Financial Studies, in press.

Bolton, Patrick and Mathias Dewatripont, Contract Theory, Cambridge, MA: MIT Press, 2005.

Boone, Audra L., Laura Casares Field, Jonathan L. Karpoff, and Charu G. Raheja, "The Determinants of Corporate Board Size and Composition: An Empirical Analysis," Journal of Financial Economics, July 2007, 85 (1), 66-101.

Booth, James and Daniel Deli, "Factors Affecting the Number of Outside Directorships Held by CEOs," Journal of Financial Economics, 1996, 40 (1), 81-104.

Borokhovich, Kenneth A., Robert P. Parrino, and Teresa Trapani, "Outside Directors and CEO Selection," Journal of Financial and Quantitative Analysis, September 1996, 31 (3), 337-355.

Bowen, William G., Inside the Boardroom: Governance by Directors and Trustees, New York: John Wiley \& Sons, 1994.

Brick, Ivan E., Oded Palmon, and John K. Wald, "CEO Compensation, Director Compensation, and Firm Performance: Evidence of Cronyism?," Journal of Corporate Finance, 2006, 12, 403-423.

Brickley, James A., Jeffrey L. Coles, and Gregg A. Jarrell, "The Leadership Structure: Separating the CEO and Chairman of the Board," Journal of Corporate Finance, 1997, 3, 189-220.

_ , _, and Rory L. Terry, "Outside Directors and the Adoption of Poison Pills," Journal of Financial Economics, 1994, 35 (3), 371-390.

Brown, Katherine M., "New Demands, Better Boards: Rethinking Director Compensation in an Era of Heightened Corporate Governance," New York University Law Review, October 2007, 82, 1102-1138. 
Bryan, Stephen and April Klein, "Non-Management Director Options, Board Characteristics, and Future Firm Investments and Performance," 2004. SSRN Working Paper 550506.

Byrd, Daniel T. and Mark S. Mizruchi, "Bankers on the Board and the Debt Ratio of Firms," Journal of Corporate Finance, March 2005, 11 (1-2), 129-173.

Calvo, Guillermo A. and Stanislaw Wellisz, "Hierarchy, Ability, and Income Distribution," Journal of Political Economy, October 1979, 87 (5, Part 1), 991-1010.

Carter, David A., Betty J. Simkins, and W. Gary Simpson, "Corporate Governance, Board Diversity, and Firm Value," The Financial Review, February 2003, 38 (1), 33-53.

Clark, Robert C., Corporate Law, Boston: Little, Brown and Company, 1986.

Cohen, Lauren, Andrea Frazzini, and Christopher Malloy, "Hiring Cheerleaders: Board Appointments of 'Independent' Directors," 2008. Harvard Business School Working Paper.

Coles, Jeffrey L., Michael L. Lemmon, and J. Felix Meschke, "Structural Models and Endogeneity in Corporate Finance: The Link Between Managerial Ownership and Corporate Finance," 2007. Working Paper, Arizona State University.

_ , Naveen D. Daniel, and Lalitha Naveen, "Boards: Does One Size Fit All?," Journal of Financial Economics, February 2008, 87 (2), 329-356.

Conyon, Martin J. and Laura E. Read, "A Model of the Supply of Executives for Outside Directorships," Journal of Corporate Finance, 2006, 12, $645-659$.

Crawford, Vincent P. and Joel Sobel, "Strategic Information Transmission," Econometrica, 1982, 50, 1431-1451.

Dahya, Jay, John J. McConnell, and Nickolaos G. Travlos, "The Cadbury Committee, Corporate Performance, and Top Management Turnover," Journal of Finance, 2002, 57 (1), 461-483.

DeGroot, Morris H., Optimal Statistical Decisions, New York: McGraw-Hill, 1970.

Deli, Daniel N. and Stuart L. Gillan, "On The Demand for Independent and Active Audit Committees," Journal of Corporate Finance, 2000, 6, 427445 .

Demb, Ada and F.-Friedrich Neubauer, The Corporate Board, Oxford: Oxford University Press, 1992. 
Demsetz, Harold and Kenneth Lehn, "The Structure of Corporate Ownership: Causes and Consequences," Journal of Political Economy, December 1985, 93 (6), 1155-1177.

Dominguez-Martinez, Silvia, Otto H. Swank, and Bauke Visser, "In Defense of Boards," Journal of Economics and Management Strategy, in press.

Eisenberg, Theodore, Stefan Sundgren, and Martin T. Wells, "Larger Board Size and Decreasing Firm Value in Small Firms," Journal of Financial Economics, April 1998, 48 (1), 35-54.

Fahlenbrach, Rüdiger, "Shareholder Rights, Boards, and CEO Compensation," Review of Finance, in press.

_, Angie Low, and René M. Stulz, "Why do Firms Appoint CEOs as Outside Directors?," 2008. Working Paper, Ohio State University.

Faleye, Olubunmi, "Are Large Boards Poor Monitors? Evidence from CEO Turnover," December 2003. Working Paper, Northeastern University.

_ , "Classified Boards, Firms Value, and Managerial Entrenchment," Journal of Financial Economics, 2007, 73, 501-559.

_, Vikas Mehrotra, and Randall Morck, "When Labor Has a Voice in Corporate Governance," Journal of Financial and Quantitative Analysis, 2006, $41(3), 489-510$.

Fama, Eugene F., "Agency Problems and the Theory of the Firm," Journal of Political Economy, 1980, 88 (2), 288-307.

Farrell, Kathleen A. and Philip L. Hersch, "Additions to Corporate Boards: The Effect of Gender," Journal of Corporate Finance, 2005, 11, $85-106$.

Ferris, Stephen P., Murali Jagannathan, and Adam C. Pritchard, "Too Busy to Mind the Business? Monitoring by Directors with Multiple Board Appointments," Journal of Finance, 2003, 58, 1087-1111.

Fich, Eliezer M., "Are Some Outside Directors Better than Others? Evidence from Director Appointments by Fortune 1000 Firms," Journal of Business, 2005, 78 (5), 1943-1971.

- and Anil Shivdasani, "The Impact of Stock-Option Compensation for Outside Directors on Firm Value," Journal of Business, 2005, 78 (6), 22292254 .

_ and _, "Are Busy Boards Effective Monitors?," Journal of Finance, 2006, $61(2), 689-724$.

- and _ , "Financial Fraud, Director Reputation, and Shareholder Wealth," Journal of Financial Economics, 2007, 86, 306-336. 
- and Lawrence White, "Why do CEOs Reciprocally Sit on Each Other's Boards?," Journal of Corporate Finance, 2005, 11, 175-195.

Fields, M. Andrew and Phyllis Y. Keys, "The Emergence of Corporate Governance from Wall St. to Main St.: Outside Directors, Board Diversity, Earnings Management, and Managerial Incentives to Bear Risk," The Financial Review, February 2003, 38 (1), 1-24.

Freedman, James O., "Presidents and Trustees," in Ronald G. Ehrenberg, ed., Governing Academia, Ithaca: Cornell University Press, 2004.

Gillan, Stuart L. and Laura T. Starks, "Corporate Goverance Proposals and Shareholder Activism: Motivation and Empirical Evidence," Journal of Financial Economics, 2000, 57, 275-305.

Gillette, Ann B., Thomas H. Noe, and Michael J. Rebello, "Corporate Board Composition, Protocols, and Voting Behavior: Experimental Evidence," Journal of Finance, 2003, 58, 1997-2031.

_ , _ , and _ , "Board Structures Around the World: an Experimental Investigation," Review of Finance, 2008, 12, 93-140.

Gilson, Stuart C., "Bankruptcy, Boards, Banks and Blockholders: Evidence on Changes in Corporate Ownership and Control when Firms Default," Journal of Financial Economics, 1990, 27, 355-387.

Goldman, Eitan, Jörg Rocholl, and Jongil So, "Do Politically Connected Boards Affect Firm Value?," Review of Financial Studies, in press.

Gompers, Paul A., Andrew Metrick, and Joy Ishii, "Corporate Governance and Equity Prices," Quarterly Journal of Economics, February 2003, 118 (1), 107-155.

Gorton, Gary and Frank A. Schmid, "Capital, Labor, and the Firm: A Study of German Codetermination," Journal of the European Economic Association, 2004, 2 (5), 863-905.

Goyal, Vidhan K. and Chul W. Park, "Board Leadership Structure and CEO Turnover," Journal of Corporate Finance, 2002, 8, 49-66.

Grandori, Anna, ed., Corporate Governance and Firm Organization, Oxford: Oxford University Press, 2004.

Graziano, Clara and Annalisa Luporini, "Ownership Concentration, Monitoring, and Optimal Board Structure," 2005. CESifo Working Paper No. 1543.

Grossman, Sanford J. and Oliver D. Hart, "An Analysis of the PrincipalAgent Problem," Econometrica, 1983, 51, 7-46.

Güner, A. Burak, Ulrike Malmendier, and Geoffrey Tate, "Financial Expertise of Directors," Journal of Financial Economics, in press. 
Guo, Re-Jin, Timothy A. Kruse, and Tom Nohel, "Undoing The Powerful Anti-Takeover Force of Staggered Boards," Journal of Corporate Finance, 2008, 14, 274-288.

Hallock, Kevin, "Reciprocally Interlocking Boards of Directors and Executive Compensation," Journal of Financial and Quantitative Analysis, September 1997, 32 (3), 331-344.

Hambrick, Donald C., Theresa S. Cho, and Ming-Jer Chen, "The Influence of Top Management Team Heterogeneity on Firms' Competitive Moves," Administrative Science Quarterly, 1996, 41, 659-684.

Harris, Milton and Artur Raviv, "A Theory of Board Control and Size," Review of Financial Studies, in press.

Hayes, Rachel M., Hamid Mehran, and Scott Schaefer, "Board Committee Structures, Ownership, and Firm Performance," 2004. Working Paper, University of Utah.

Hermalin, Benjamin E., "Heterogeneity in Organizational Form: Why Otherwise Identical Firms Choose Different Incentives for their Managers," RAND Journal of Economics, Winter 1994, 25 (4), 518-537.

_ , "Higher Education Boards of Trustees," in Ronald G. Ehrenberg, ed., Governing Academia, Ithaca: Cornell University Press, 2004.

_ , "Trends in Corporate Governance," Journal of Finance, 2005, 60 (5), 23512384 .

- and Michael L. Katz, "Moral Hazard and Verifiability: The Effects of Renegotiation in Agency," Econometrica, November 1991, 59 (6), 1735-1753.

- and Michael S. Weisbach, "The Determinants of Board Composition," RAND Journal of Economics, Winter 1988, 19 (4), 589-606.

_ and _ , "The Effects of Board Composition and Direct Incentives on Firm Performance," Financial Management, Winter 1991, 20 (4), 101-112.

_ and _ , "Endogenously Chosen Boards of Directors and Their Monitoring of the CEO," American Economic Review, March 1998, 88 (1), 96-118.

_ and _, "Boards of Directors as an Endogenously Determined Institution: A Survey of the Economic Literature," Economic Policy Review, April 2003, $9(1), 7-26$.

_ and _ , "Information Disclosure and Corporate Governance," 2008. University of California Working Paper.

- and Nancy E. Wallace, "Firm Performance and Executive Compensation in the Savings and Loan Industry," Journal of Financial Economics, 2001, 61, 139-170. 
Himmelberg, Charles P., R. Glenn Hubbard, and Darius Palia, "Understanding the Determinants of Managerial Ownership and the Link between Ownership and Performance," Journal of Financial Economics, September 1999, 53 (3), 353-384.

Hirshleifer, David and Anjan V. Thakor, "Managerial Performance, Boards of Directors, and Takeover Bidding," Journal of Corporate Finance, 1994, 1 (1), 63-90.

Holmstrom, Bengt, "Moral Hazard and Observability," Bell Journal of Economics, Spring 1979, 10 (1), 74-91.

_ , "Moral Hazard in Teams," The Bell Journal of Economics, Autumn 1982, $13,324-340$.

_ , "Managerial Incentive Problems - A Dynamic Perspective," Review of Economic Studies, January 1999, 66 (226), 169-182.

_ , "Pay without Performance and the Managerial Power Hypothesis: A Comment," Journal of Corporation Law, 2005, 30, 703-713.

Huson, Mark R., Robert Parrino, and Laura T. Starks, "Internal Monitoring Mechanisms and CEO Turnover: A Long-Term Perspective," Journal of Finance, December 2001, 55 (6), 2265-2297.

Hwang, Byoung-Hyoun and Seoyoung Kim, "It Pays to Have Friends," Journal of Financial Economics, in press.

Jarrell, Gregg and Annette Poulsen, "Shark Repellents and Stock Prices: The Effects of Antitakeover Amendments Since 1980," Journal of Financial Economics, 1987, 19, 127-168.

Jensen, Michael C., "The Modern Industrial Revolution, Exit, and the Failure of Internal Control Systems," Journal of Finance, 1993, 48 (3), 831-880.

Jenter, Dirk and Fadi Kanaan, "CEO Turnover and Relative Performance Evaluation," 2008. MIT Working Paper.

John, Kose and Lemma W. Senbet, "Corporate Governance and Board Effectiveness," Journal of Banking \& Finance, May 1998, 22 (4), 371-403.

Kaplan, Steven N. and Bernadette A. Minton, "How has CEO Turnover Changed? Increasingly Performance Sensitive Boards and Increasingly Uneasy CEOs," July 2006. Unpublished working paper, University of Chicago GSB.

- and David Reishus, "Outside Directorships and Corporate Performance," Journal of Financial Economics, 1990, 27 (2), 389-410. 
Klausner, Michael, Bernard S. Black, and Brian R. Cheffins, "Outside Directors Liability: Have WorldCom and Enron Changed the Rules?," Stanford Lawyer, Winter 2005, (71), 36-39.

Klein, April, "Firm Performance and Board Committee Structure," Journal of Law and Economics, 1998, pp. 137-165.

_ , "Audit Committee, Board of Director Characteristics, and Earnings Management," Journal of Accounting and Economics, 2002, 33, 375-400.

Kofman, Fred and Jacques Lawarrée, "Collusion in Hierarchical Agency," Econometrica, May 1993, 61 (3), 629-656.

Kramarz, Francis and David Thesmar, "Social Networks in the Boardroom," 2006. IZA Discussion paper No. 1940.

Kumar, Praveen and K. Sivaramakrishnan, "Who Monitors the Monitor? The Effect of Board Independence on Executive Compensation and Firm Value," Review of Financial Studies, 2008, 21 (3), 1371-1401.

Larcker, David F., Scott A. Richardson, Andrew J. Seary, and Irem Tuna, "Director Networks, Executive Compensation and Organizational Performance," 2005. Working paper, The Wharton School.

Laux, Volker, "Board Independence and CEO Turnover," Journal of Accounting Research, 2008, 46, 137-171.

Lehn, Kenneth, Sukesh Patro, and Mengxin Zhao, "Determinants of the Size and Structure of Corporate Boards," Financial Management, in press.

Linck, James S., Jeffry M. Netter, and Tina Yang, "The Determinants of Board Structure," Journal of Financial Economics, 2008, 87, 308-387.

_ , _ , and _ , "The Effects and Unintended Consequences of the SarbanesOxley Act on the Supply and Demand for Directors," Review of Financial Studies, in press.

Lorsch, Jay W. and Elizabeth MacIver, Pawns or Potentates: The Reality of America's Corporate Boards, Boston: Harvard Business School Press, 1989.

Lublin, Joann S., "Corporate Whistle-Blowers Can Salvage Their Careers," Wall Street Journal, February 6, 2002, on line.

MacAvoy, Paul and Ira M. Millstein, "The Active Board of Directors and Its Effect on the Performance of the Large Publicly Traded Corporation," Journal of Applied Corporate Finance, 1999, 11 (4), 8-20.

_, Scott Cantor, James D. Dana Jr., and Sarah Peck, "ALI Proposals for Increased Control of the Corporation by the Board of Directors: An Economic Analysis," in "Statement of the Business Roundtable on the American Law Institute's Proposed Principles of Corporate Governance and Structure: Restatement and Recommendations," New York: Business Roundtable, 1983. 
Mace, Myles L., Directors: Myth and Reality, Boston: Harvard Business School Press, 1971.

Mahoney, James M. and Joseph T. Mahoney, "An Empirical Investigation of the Effect of Corporate Charter Amendments on Stockholder Wealth," Strategic Management Journal, 1993, 14, 17-32.

Maskin, Eric and Jean Tirole, "Unforeseen Contingencies and Incomplete Contracts," Review of Economic Studies, January 1999, 66 (1), 83-114.

Murphy, Kevin J. and Ján Zábojník, "Managerial Capital and the Market for CEOs," December 2003. Marshall School of Business Working Paper, University of Southern California.

_ and _, "CEO Pay and Appointments: A Market-Based Explanation for Recent Trends," American Economic Review, May 2004, 94 (2), 192-196.

Naveen, Lalitha, "Organizational Complexity and Succession Planning," Journal of Financial and Quantitative Analysis, 2006, 41, 661-683.

Palia, Darius, "The Endogeneity of Managerial Compensation in Firm Value: A Solution," Review of Financial Studies, Autumn 2001, 14 (3), 735-764.

Parrino, Robert, "CEO Turnover and Outside Succession: A Cross-Sectional Analysis," Journal of Financial Economics, 1997, 46, 165-197.

Perry, Tod, "Incentive Compensation for Outside Directors and CEO Turnover," 1999. Working Paper, Arizona State University.

Pfeffer, Jeffrey, "Size and Composition of Corporate Boards of Directors: The Organization and its Environment," Administrative Science Quarterly, 1972, 17, 218-229.

Raheja, Charu G., "Determinants of Board Size and Composition: A Theory of Corporate Boards," Journal of Financial and Quantitative Analysis, June 2005, 40 (2), 283-306.

Ravina, Enrichetta and Paola Sapienza, "What Do Independent Directors Know? Evidence from Their Trading," Review of Financial Studies, in press.

Rechner, Paula L. and Dan R. Dalton, "CEO Duality and Organizational Performance: A Longitudinal Analysis," Strategic Management Journal, 1991, 12, 155-160.

Roe, Mark, Strong Managers, Weak Owners: The Political Roots of American Corporate Finance, Princeton, NJ: Princeton University Press, 1994.

Ryan, Harley and Roy Wiggins, "Who is in Whose Pocket? Director Compensation, Bargaining Power, and Board Independence," Journal of Financial Economics, 2004, 73, 497-524. 
Shavell, Steven, "Risk Sharing and Incentives in the Principal and Agent Relationship," Bell Journal of Economics, Spring 1979, 10 (1), 55-73.

Shivdasani, Anil, "Board Composition, Ownership Structure, and Hostile Takeovers," Journal of Accounting and Economics, Jan./April/July 1993, 16 (1/2/3), 167-198.

- and David Yermack, "CEO Involvement in the Selection of New Board Members: An Empirical Analysis," Journal of Finance, 1999, 54, 1829-1853.

Smith, Adam, An Inquiry into the Nature and Causes of the Wealth of Nations, Indianapolis: Liberty Press, 1776.

Song, Fenghua and Anjan V. Thakor, "Information Control, Career Concerns, and Corporate Governance," Journal of Finance, August 2006, 61 (4), $1845-1896$.

Tirole, Jean, "Hierarchies and Bureacracies: On the Role of Collusion in Organizations," Journal of Law, Economics, 83 Organization, Fall 1986, 2 (2), $181-214$.

_ , "Collusion and the Theory of Organizations," in Jean-Jacques Laffont, ed., Advances in Economic Theory: 6th World Congress, Cambridge, England: Cambridge University Press, 1992.

Vafeas, Nikas, "Determinants of the Adoption of Director Incentive Plans," Journal of Accounting, Auditing \& Finance, Fall 1999, 14 (4), 453-474.

Vancil, Richard F., Passing the Baton: Managing the Process of CEO Succession, Boston: Harvard Business School Press, 1987.

Warner, Jerold B., Ross L. Watts, and Karen H. Wruck, "Stock Prices and Top-Management Changes," Journal of Financial Economics, Jan./March 1988, 20 (1/2), 461-492.

Warther, Vincent A., "Board Effectiveness and Board Dissent: A Model of the Board's Relationship to Management and Shareholders," Journal of Corporate Finance, 1998, 4 (1), 53-70.

Weisbach, Michael S., "Outside Directors and CEO Turnover," Journal of Financial Economics, Jan./March 1988, 20 (1/2), 431-460.

Westphal, James D., "Collaboration in the Boardroom: Behavioral and Performance Consequences of CEO-Board Social Ties," Academy of Management Journal, 1999, 42 (1), 7-24.

- and Edward J. Zajac, "Who Shall Govern? CEO/Board Power, Demographic Similarity, and New Director Selection," Administrative Science Quarterly, 1995, 40, 60-83. 
Whisler, Thomas L., The Rules of the Game: Inside the Corporate Boardroom, Homewood, IL: Dow Jones-Irwin, 1984.

Williamson, Oliver E., Markets and Hierarchies: Analysis and Antitrust Implications, New York: The Free Press, 1975.

_ , "Franchise Bidding for Natural Monopolies - in General and with Respect to CATV," The Bell Journal of Economics, Spring 1976, 7 (1), 73-104.

Xie, Biao, Wallace N. Davidson III, and Peter J. DaDalt, "Earnings Management and Corporate Governance: The Role of the Board and the Audit Committee," Journal of Corporate Finance, 2003, 9, 295-316.

Yermack, David, "Higher Valuation of Companies with a Small Board of Directors," Journal of Financial Economics, 1996, 40 (2), 185-212.

_ , "Remuneration, Retention, and Reputation Incentives for Outside Directors," October 2004, 59 (5), 2281-2308.

_. "Board Members and Company Value," Financial Markets and Portfolio Management, 2006, 20, 33-47.

Zajac, Edward J. and James D. Westphal, "Director Reputation, CEOBoard Power, and the Dynamics of Board Interlocks," Administrative Science Quarterly, 1996, 41, 507-529. 